\title{
A Justice's Surprise That Has Stood Its Ground: The Enduring Value of the Commercial Speech Doctrine's Powellian Balance
}

\author{
Robert L. Kerr
}

(C) 2011

BY THE ASSOCIATION FOR EDUCATION IN JOURNALISM

AND MASS COMMUNICATION

Robert L. Kerr is an associate professor in the College of Journalism and Mass Communication at the University of Oklahoma. 


\begin{abstract}
One of the most important concepts of modern commercial speech related to advertising, characterized as the "Powellian balance," resulted in a compromise between those who thought commercial expression should receive little or no First Amendment protection and those who argued that it receive the same expansive protection accorded to political expression. The private papers of Justice Lewis F. Powell, Jr. reveal the remarkable degree to which he maintained a deep commitment to balancing competing interests in shaping the commercial speech doctrine. The central argument of this monograph is that Powell's "middle way" can be employed to best promote today's vital and complex societal interests.
\end{abstract}




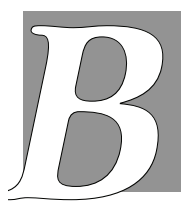

efore Lewis F. Powell, Jr. could use "Justice” before his name, the corporate attorney wrote an opinion for the U.S. Chamber of Commerce that was a virtual battle cry for maximizing business clout in the media and in the courts. Those who read the once secret and widely influential memorandum were later surprised in the early spring of 1980 when Justice Powell wrote the majority opinion in the most important commercial speech case to that time or since-most anticipated a ruling more unequivocally advantageous to business interests.

After a decade on the Court, Justice Powell had seven justices who had expressed support in conference for striking down the advertising regulation that had been challenged in the case on First Amendment grounds. Quite arguably, he could have found a way to do not only that but to do so in a manner that would have placed commercial speech on equal footing with the broader constitutional protections of political speech — or at least something much closer. Indeed, he could have sought to sweep away the doctrinal distinctions the Court had long maintained that kept commercial advertising relatively less protected from regulation by the First Amendment.

Instead, Justice Powell poured considerable labors into firmly and enduringly embedding those distinctions in the case law while paradoxically, to many, doing much the same thing to promote broad protections for commercial speech. Furthermore, based on what the historical record reveals of his intentions, he pulled it off. In doing so he hammered into place a challenging, often maddening, and much challenged judicial tool for maintaining balance between two fiercely competing societal interests. The first time Justice Powell employed it, he himself found it agonizing to apply in practice. Many scholars and jurists have argued since that it is too diffi- 
cult, inconsistent, ineffective, and so on. Yet well into the twenty-first century, Justice Powell's creation endures. In terms of societal interests, this monograph proposes that it is a good thing that it does.

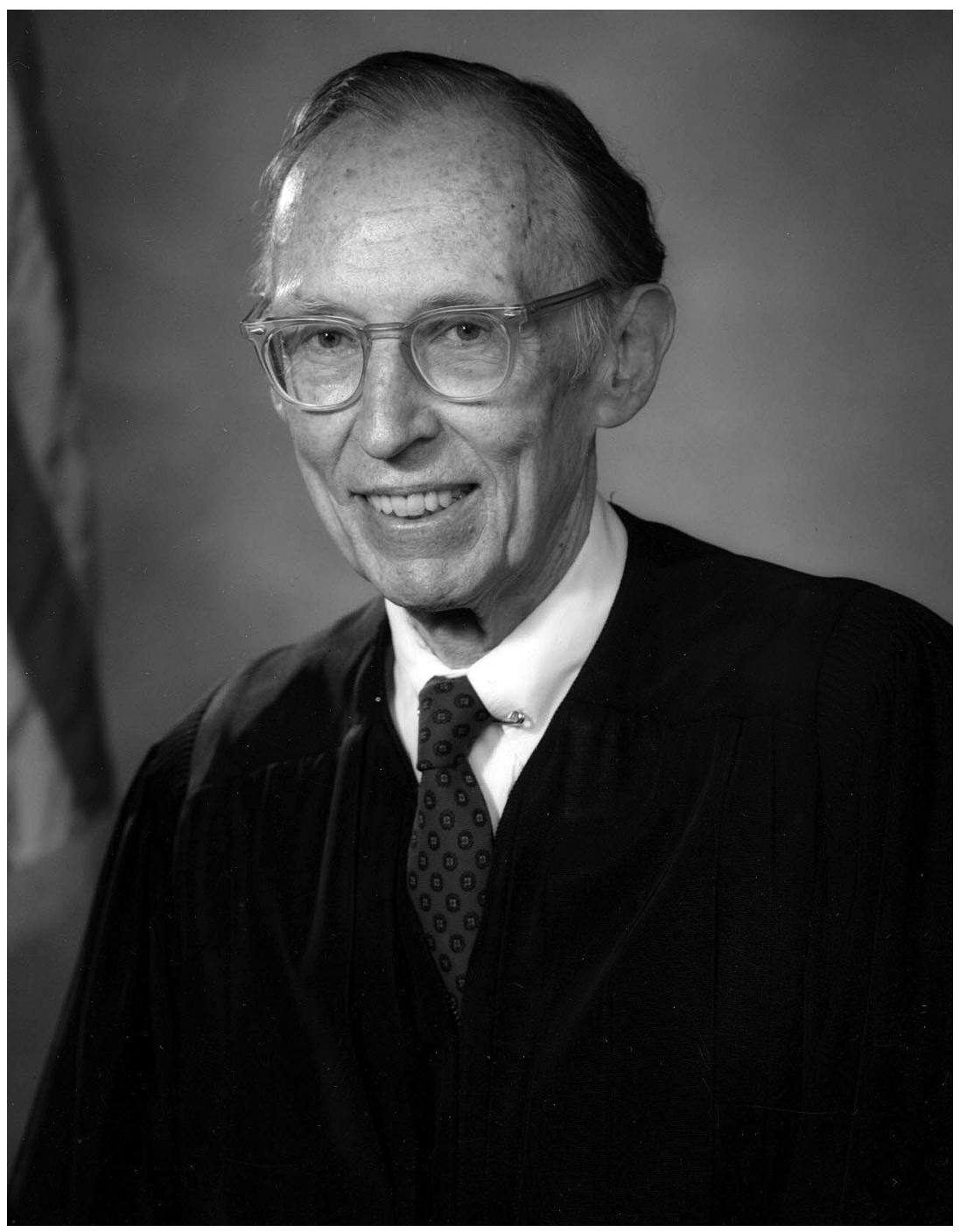

Justice Lewis F. Powell, Jr.

Used by permission from the Lewis F. Powell, Jr. Archives, Washington and Lee University School of Law 


\section{Introduction}

It is almost a half-century since the development of the modern First Amendment doctrine on commercial speech that began in the United States Supreme Court. It is now possible to place the considerable changes wrought by that process in fuller theoretical and historical context. The central argument of this monograph is that the contentious debate over the Court's jurisprudence regarding constitutional protection for advertising can be moved forward through enhanced understanding of its anchoring in broader, time-tested wisdom on how to best promote vital but complex societal interests. Such an understanding offers considerable ground for resolution between the divided camps of scholars who argue, often ideologically, either that commercial expression should receive little or no First Amendment protection, or that it should receive the same expansive protection accorded to political expression and thus be essentially unburdened from any regulation. Considering the subject in context to a long view of human experience advances significant support for historically grounded principles of sound business law and practice over ideology, principles that stand in contrast to the hazards of ideologically driven imbalance in economic affairs more broadly.

Advancing an understanding in favor of what is characterized here as "Powellian balance" will begin with a synthesis of the voluminous literature on commercial speech, utilizing an explicative spectrum of values between the freedom of the informational component of advertising on one end and the preservation of the fair-bargaining process implicated in the contractual component of such speech at the other. The tension of that dualistic conflict established, the monograph would articulate how the theoretical centrality of that difficult but vital equilibrium of values has been maintained in modern commercial speech jurisprudence for more than three decades.

The influence of Powell's compromise will be demonstrated through analysis focused upon development of its formative cases as documented in the private papers of one of the most influential justices involved in the process. Those papers reveal the remarkable degree to which Justice Lewis F. Powell, Jr. - whose career background and well-documented agenda before joining the Supreme Court arguably made him the most experientally business-oriented justice there in recent decades - maintained a deep commitment to balancing competing interests in shaping the commercial speech doctrine. That effort markedly strove to resist tilting the related body of jurisprudence excessively out of balance in either direction. That is, the process resulted in establishing a structural mechanism that serves to preserve an adjudicational focal point that always remains, over time, somewhere between absolute freedom of the informational component of advertising and excessively suppressive enforcement of the fair-bargaining process implicated in the contractual component of such speech. Justice Powell's deep background in historically grounded principles of sound business law, experience, and practice guided his creative and tenacious 
judicial assertion of his own unwavering commitment toward maintaining that fundamental balance. And it is precisely that balance that Justice Powell intended to - and did - institutionalize in constitutional considerations of First Amendment questions concerning commercial speech ever since. As will be articulated, the fact that it has produced what on the surface may seem contradictory rulings represents not the failure of Powellian balance but rather its ongoing success.

In broad strokes, the Supreme Court's doctrine on First Amendment protection for commercial speech can be bracketed reasonably distinctly in terms of three historical phases. ${ }^{1}$ In the first, the Court devoted little attention to the subject, and when it did, declared advertising to be a form of expression existing somewhere well outside the shelter of constitutional protections for freedom of speech. That approach ended in the 1970s when the Court over a series of cases spanning the decade made commercial speech a priority in its First Amendment cases and established an intermediate level of protection for advertising. The ruling meant that judicial review of challenged regulations of commercial speech be conducted at a level of scrutiny between high, applied to regulation of political expression and low, applied to regulations that do not infringe upon fundamental rights. $^{2}$

The central case is the Court's decision in Central Hudson Gas and Electric v. Public Service Commission ${ }^{3}$ in which Justice Powell developed a four-part test for assessing the constitutionality of government regulations on advertising that are challenged on First Amendment grounds. ${ }^{4}$ While the second phase cannot truly be said to have ended — given that the Hudson test remains central to the Court's commercial speech doctrine - a relatively more rigorous evolution of that test's application can be seen in a third level that evolved significantly in the early 1990s. The major commercial speech cases since can be distinguished by an unsparing determination to deny government the power to intervene in advertising that disseminates truthful information - even for the purpose of discouraging consumption of legal but socially problematic products such as alcohol and tobacco. ${ }^{5}$

As will be discussed, the Court's development on this issue generated ongoing debate in the literature and among justices over the degree of First Amendment protection that should be accorded to commercial speech. This monograph considers that debate in terms of the inherent difficulties in assessing expression that not only talks about a product or service, but also sells it. In that respect, advertising has been characterized as "speech in the service of selling." 6 The problem involved can be conceptualized more fully by considering commercial speech as a form of expression that inherently comprises both informational and contractual elements. That is, to the extent that an advertisement serves an informative function, it represents the sort of expression that the First Amendment protects. But to the extent that it makes promises to potential buyers, it "can be seen as constituting part of the contractual arrangement between the buyer and seller." As such, advertising is subject to different considerations, since "[c]ontract law consists almost entirely of rules attaching liability to various uses of language," 
as Farber has observed, and "the use of language to form contracts is not the sort of 'speech' to which the First Amendment applies."7

This monograph comprises an array of "bold, and boldly conflicting, solutions to the question of what judicial protection is appropriate to commercial speech," as Cass put it in an influential 1988 article. ${ }^{8}$ He wrote at a time when most of the Supreme Court's commercial speech rulings reflected a relatively higher degree of agreement among the justices than would be the case later. ${ }^{9}$ In short, as will be discussed in more detail, the spectrum of those solutions ranges from granting commercial speech the same First Amendment protections as political speech to granting it none of those protections - along with a number of proposals for various intermediate protections.

Cass's assessment of the literature concluded that the "general contours of the Court's commercial speech decisions are in keeping with history, precedent, and sound analysis, while strong objections to these decisions often rest on less easily defended views of constitutional interpretation generally and of the First Amendment in particular."10 The purpose of this monograph is to extend analysis grounded in that vein so as to consider the degree to which the formative years of the Court's modern commercial speech jurisprudence reflect philosophical consistency with historically grounded principles of sound business law, experience, and practice. That objective will be advanced through an assessment of the literature.

That section will be followed by analysis of development of the formative cases of modern commercial speech jurisprudence, as documented in the private papers of the justice whose extensive efforts in shaping those cases established the most enduring influence upon the Court's ongoing doctrine concerning advertising and the First Amendment. Justice Powell, who died in 1988, came to the Court in 1972 as part of a well-documented and historically significant effort to expand the influence of business on the Court and in the media - an effort he was instrumental in launching. ${ }^{11}$ Justice Powell brought considerable personal experience in the business community to the Court, joining it at the age of sixty-four after a long career as one of the nation's most successful corporate attorneys, which included serving on the boards of directors of a number of large companies. ${ }^{12} \mathrm{He}$ joined the Court as one of four new justices appointed by President Richard M. Nixon, with the goal of remaking it in reaction to what the president saw as the "adventurous egalitarianism" it had pursued under Chief Justice Earl Warren over the previous two decades. ${ }^{13}$

Through historical and legal analysis of the relevant memoranda, correspondence, and other documents in his private Court papers, this study employs a methodological approach that offers insights beyond what is available in published rulings of the Court. The extensive files that Justice Powell kept offer researchers a window into the way interactions involving him and his fellow justices critically shaped the nature of a series of groundbreaking rulings. That view provides a remarkably full, detailed, and nuanced understanding of how one determined justice overcame considerable challenges over the course of the robust debate at the Court during the 
nascent years of the modern commercial speech doctrine's development. Ultimately he firmly secured a doctrinal framework consistent with the philosophical and experiental cornerstones of his own most fundamental convictions on how to best promote vital but complex societal interests.

\section{The Literature and its Informational/ Contractual Divide}

As proposed in the introduction, this monograph considers the literature on commercial speech within a framework of the dualistic informational/contractual nature of that form of expression. That is, it seeks understanding through scholarly research that promotes the informational or contractual element or a middle way. Broadly, an emphasis on the informational element represents commercial speech in terms of an abstract freedom of expression. Conversely, an emphasis on the contractual element conceptualizes commercial speech within the area of transactional promises between the seller and buyer that are not First Amendment concerns.

One of the earliest arguments of the latter can be seen in Jackson and Jeffries' assertion that while "disallowing state interference with commercial advertising serves other values that merit careful legislative consideration - aggregate economic efficiency and consumer opportunity to maximize utility in a free market - these values are not appropriate for judicial vindication under the First Amendment." 14 Also early in the Supreme Court's development of its modern commercial speech doctrine, Coase put forth the counter-position with similar prominence contending that "once the informational value of price advertising is recognized, it seems difficult to deny all value to the advertising of other qualities," and by that reasoning such expression warrants expansive First Amendment protection. ${ }^{15}$ Thus, those two perspectives offer representations that can serve to approximate the extremes of literature on commercial speech related to advertising in the last four decades.

Those perimeters can be distinguished more fully in the considerable scholarship of Baker and Redish. Baker stressed his analysis that historically, "Our strongest advocates of free speech" — such as political theorist John Stuart Mill, Justice Hugo Black, and civil liberties scholar Thomas Emerson - "each consistently rejected granting any protection to commercial speech.... [None] saw freedom of speech as about, or as including, a business's speech promoting its sales and profits." 16 While the early cases such as Virginia Pharmacy "churned sympathy as essentially consumer protection cases,"17 Baker pointed out, "subsequent popular advocacy of constitutional protection for commercial speech has been powerfully promoted by corporate interests - from groups such as the American Association of Advertising Agencies." 18 In contrast, Redish focused on an articulation of marketplace-of-ideas theory that is framed in terms of listeners freely receiving information to "supply ... theoretical support" for "the extension of full First Amendment protection to commercial speech." 19 In his view, most of the opposition to extending such protection undermines freedom of expres- 
sion because it "may be deconstructed into little more than a result-oriented attempt to stifle advocacy of a particular ideological perspective or point of view. The First Amendment guarantee cannot be allowed to be manipulated in such a manner."20

Baker counters the viewpoint-discrimination contention by noting that regulations on commercial speech actually do not restrict any particular viewpoint that is not part of messages that represent potential commercial transactions with consumers: "Any regulation of commercial speech leaves people on all sides of the world-wide debate completely free to present their views and their understanding of the facts" outside that context. ${ }^{21}$ Redish articulated the essence of their differences in terms that delineate their respective positions in relation to the informational/contractual divide. It "flows from our respective beliefs concerning the relevance for First Amendment purposes of the receipt, as opposed to merely the expression, of information, opinion, and thought," he wrote. Because "the value of selfrealization, as I define it, may be fostered as much by the receipt of expression as by the act of expressing, I conclude that the source or motivation of the expression is largely irrelevant."22

The early years of the modern commercial speech doctrine generated an impressive body of work roughly along the lines of that spectrum. It made the case that the Supreme Court was correct in maintaining a subordinate status for commercial speech in First Amendment jurisprudence, ${ }^{23}$ disparaged the Court's efforts to continue distinctions between commercial and noncommercial speech in that jurisprudence, ${ }^{24}$ and advanced arguments for approaching the question along a middle ground between the first two camps. ${ }^{25}$ Subsequently, the Court issued rulings that struck down regulations on the advertising of alcohol and tobacco - products that were legal for adults but nevertheless implicated in such serious health concerns that regulation of their promotion had long been thought well within the bounds of the government's purview. ${ }^{26}$ The decisions suggested a shift toward an assessment of advertising as purely informational and thus worthy of greater First Amendment protections, generating a vein of scholarship that asserted the Court had announced the "last call" for maintaining "the untenable distinction between commercial and noncommercial speech."27

To many, the Court appeared so poised to leap that it seemed to justify rhapsodizing that its "love affair ... [had] ended" with the complex balancing the Central Hudson test had maintained between the informational and contractual elements of advertising. ${ }^{28}$ Certainly, as Sullivan expressed it, such rulings raised questions that made it "unclear why "commercial speech' should continue to be treated as a separate category of speech isolated from general First Amendment principles." 29 Minimally, the trend seemed to be "toward, although still shy of, affording commercial speech the same level of protection other forms of protected speech enjoy." 30 Warnings ensued that protected such forms of advertising actually promoted subtler forms of deception through which products such as cigarettes and alcohol "are selling the addict's solution, telling us that our problems can be effortlessly solved by the purchase of a product, ... [when] even marketers 
themselves know that things like relationships, self-esteem, and love cannot be provided by a product.... In this respect, deception is as integral a part of commercial advertising as it is of addiction." 31

For Piety, that represented an early assertion of the broader question she would examine extensively in the years ahead, exploring whether such an expansive "architecture of the First Amendment with respect to commercial speech is one we can afford to live with." ${ }^{2}$ Other scholarship has similarly focused upon the evolving nature of modern advertising as a subtler and more pervasive form of deceptiveness that arguably serves to undermine consideration of the contractual element in the Court's evolving jurisprudence on commercial speech. In a pair of articles from that period, Collins and Skover considered at some length the way that "today's mass advertising often has ... less to do with facts than image" and thus can be understood as "more a total cultural system than an exclusively informational one ... [in which] truth is that which sells." 33 In that milieu they maintained constitutional protection for such expression is effectively advancing "talismanically" through a process that "appropriates the symbols of informational advertising, reconstructs them in its own image, and returns them to the legal community in the form of constitutional defenses," institutionalizing in the case law "an ignoble lie." 34

The next decade saw a considerable burst of related literature inspired by a Supreme Court ruling that never happened. Even though the Court had agreed to hear 2003's Nike, Inc. v. Kasky, ${ }^{35}$ accepted a total of thirty-four briefs from the parties involved and amici (friend of the court), and heard oral arguments, it ultimately decided not to decide the case. ${ }^{36}$ That non-call left in place a California Supreme Court ruling that the messages in a public relations and advertising campaign by Nike, Inc., were subject to regulation under California's commercial speech laws and could proceed to trial. ${ }^{37}$ A concurring opinion by Justice John Paul Stevens and joined by two other justices attributed the dismissal to procedural problems that would make adjudication by the high Court premature. ${ }^{38}$ Justice Stephen Breyer challenged that reasoning and was joined by Justice Sandra Day O'Connor. ${ }^{39}$ Activist Mark Kasky had sued Nike over its campaign alleging that it made false and misleading statements regarding so-called unsafe and abusive working conditions in factories where the multinational corporation's athletic shoes and apparel were manufactured. ${ }^{40}$ As its defense, Nike argued that the campaign was protected as political speech on a subject of public debate - and thus not subject to any regulation on its commercial speech. However, when that argument was not successful, the case was settled out of court. ${ }^{41}$ Nike agreed to pay $\$ 1.5$ million to the Fair Labor Association, a Washington-based group that monitors corporate labor practices abroad and helps educate workers. ${ }^{42}$ Kasky and Nike said in a joint statement that supporting such programs was preferable to continued litigation. ${ }^{43}$ That ended the litigation, but not by any means the scholarly debate.

One line of argument asserted that the difficult questions presented by the Nike case demonstrated that the Supreme Court should stop trying to maintain a line between commercial and noncommercial speech in its First 
Amendment jurisprudence. "[T]he line is so blurred as to be indistinguishable. With greater frequency and subtlety, new technologies and innovative marketing strategies introduce corporate profit-motive into what otherwise would be fully protected speech. The current commercial speech doctrine cannot predictably resolve disputes resulting from these new modes of expression," La Fetra contended. ${ }^{44}$ "Even when the speech is fairly straightforward in its attempt to bolster the bottom line, it is so frequently intermingled with otherwise protected speech that courts simply cannot determine where the speech falls in the tangled web of cases comprising the "commercial speech doctrine." 45 For Terilli, Nike "demonstrated the danger as well as the difficulty of trying to distinguish commercial speech from other speech," 46 and he proposed that commercial speech should be fully protected unless it includes a "consummated, proposed or intended transaction to which an actual injury could be attributed." ${ }^{7}$ Johnson and Fisher essayed similarly that commercial speech should be narrowly defined on the basis of a standard limited to "statements made in the course of economic transactions." 48 Rather than seeking to hold business corporations to "a higher standard of truthfulness in all of their public communications on subjects that might influence consumers," the purpose of the commercial speech doctrine should be "merely to allow the government to ensure that consumers are accurately informed about products and services in the marketplace." 49

Such calls for narrowing the reach of commercial speech jurisprudence were countered by scholarship that argued the case showed instead that complex, new advertising methods called for an opposite approach. Maintaining that the courts involved had rightly denied granting the corporation a "constitutional right to lie," Piety catalogued the implications of protecting more broadly speech such as that at issue in Nike, in which the lawsuit "didn't just allege that Nike had disseminated false information" but that "Nike had intentionally disseminated false information." 50 In an article that focused on the linkage between regulatory enforcement efforts such as Kasky's and the prevention of actual harms that may be deceptively represented in commercial speech, Fisher contended that Nike-style lawsuits offer some potential for constructively influencing corporate labor practices. ${ }^{51}$ Bennigson argued that "all speech by publicly traded for-profit business corporations is commercial" and thus the answer to questions presented by such cases as Nike should be simply to classify all speech by commercial corporations as commercial speech, without regard to its content. ${ }^{52}$ In a cautionary note regarding such assertions to shift commercial speech jurisprudence so far in that direction, Collins and Skover warned that the ruling against Nike potentially could well cut just as deeply against those who saw it as a means to force corporations to be more truthful, arguing that the messages of consumer advocates could be vulnerable to litigation challenging its veracity. ${ }^{53}$

More recent works highlight the expansive range of efforts to push for evolving commercial speech jurisprudence so as consider more types of speech as informational and bring them within the protection of the First 
Amendment. Page has proposed, for example, that communications between publicly traded companies and their current and prospective investors should qualify, contending there is "little, if any, justification for securities regulations that restrict or burden speech." 54 Erickson argued for extending such protection to counter recent regulations on telemarketing and junk-faxes, maintaining that " $[\mathrm{t}] \mathrm{o}$ make the householder the exclusive and final judge of what will cross his threshold undoubtedly has the effect of impeding the flow of ideas, information, and arguments that, ideally, he should receive and consider." 55 Conversely, arguments for taking the commercial speech doctrine in the other direction have made the case for adapting it so as to allow for more restrictive regulation of such recently proliferating practices as junk-food advertising to children, ${ }^{56}$ "undercover-marketing" techniques, ${ }^{57}$ and brand-sponsored "peer promotions." 58 More broadly, Piety's analysis of the modern metamorphosis through which corporate marketing has moved away from the explicit claims of traditional advertising to public relations techniques - which advance the same commercial objectives but are more difficult and often impossible to test for truth in terms of the current commercial speech doctrine - made the case for a doctrine that protects less of such expression as informational, rather than more. ${ }^{59}$ She concluded that in response the doctrine must evolve so as to more broadly hold "entities seeking to profit from information injected into the stream of commerce ... accountable for the quality of that information."60

\section{The Literature and the Overriding Weight of Case Law}

In order to most fully place the body of literature on modern commercial speech jurisprudence in perspective, it is vital to emphasize that the most enduring constant over the greatest part of its development is the continued reliance on the Central Hudson test and its structural role in maintaining an intermediate level of protection for commercial speech. Even in more recent commercial speech cases in which some justices have questioned that central component of the doctrine and suggested treating such expression more like political speech, the Court's majority has never embraced such a shift. Revisions of the doctrine have over time proven more accurately to focus on preventing government from denying citizens truthful information disseminated via advertising, especially when the regulation involves using speech restrictions to discourage activities that are otherwise legal. ${ }^{61}$

Yet, the centrality and essential relevance of the Central Hudson test in commercial speech jurisprudence remains intact, despite much critique in the literature. ${ }^{62}$ Indeed, its vitality can be seen in the way that the repeated efforts of some justices have failed to win a majority at the Court. For example, in a concurring opinion in 1993's Cincinnati v. Discovery Network, which struck down a city ban on the use of newsracks on city streets to distribute commercial handbills, Justice Harry A. Blackmun wrote that he hoped the Court would ultimately "abandon Central Hudson's analysis entirely." 63 In the Court's splintered 44 Liquormart v. Rhode Island, ${ }^{64}$ a sixjustice majority agreed on the judgment striking down two Rhode Island 
statutes limiting advertisement of alcohol prices to the point of purchase, but the nine justices split into five alignments with varied memberships of three or four justices each to join selected parts of Justice Stevens' eight-part principal opinion. ${ }^{65}$ Two other justices joined his argument that more rigorous scrutiny than Central Hudson's intermediate inspection should be applied to regulations that entirely prohibit "the dissemination of truthful, nonmisleading commercial messages for reasons unrelated to the preservation of a fair bargaining process." 66 But four other justices specifically rejected any such refashioning of established doctrine. ${ }^{67}$

Therefore, the Central Hudson test remains the standard for determining through intermediate scrutiny the constitutionality of advertising regulations that are challenged on First Amendment grounds. It is quite routinely employed in the courts for that purpose, including in prominent recent cases as the basis for upholding regulation on commercial speech such as "do not call" restrictions on telemarketing ${ }^{68}$ and lottery advertising, ${ }^{69}$ and for striking down regulations on advertising involving alcohol content ${ }^{70}$ and prices $^{71}$ and tobacco billboards. ${ }^{72}$ In 2001's Lorillard Tobacco v. Reilly, the petitioners urged the Court to "reject the Central Hudson analysis and apply strict scrutiny" on the grounds that several justices had "expressed doubts about the Central Hudson analysis and whether it should apply in certain cases. ${ }^{73}$ The majority firmly declined - just as it had in response to a similar case two years before: "We see 'no need to break new ground. Central Hudson, as applied in our more recent commercial speech cases, provides an adequate basis for decision.",74

\section{The Hudson-Centric Doctrine's Principled Grounding}

This monograph will now proceed with developing the argument that considerable explanation for the longevity of that Hudson-centric doctrine can be seen in the philosophical resonance with historically grounded principles of sound business law, experience, and practice deriving from the priorities of the Powell Era Court. ${ }^{75}$ In particular, those priorities can be seen to maintain a fundamental commitment to the difficult balancing between the values of freedom of expression and the fair-bargaining process. Stern has characterized the commercial speech jurisprudence forged in that era and essentially maintained by the Court since as representing "a healthy pragmatism, not jurisprudential failure... The Court has developed a flexible but coherent method of identifying commercial speech commensurate with the complexity of the subject and the needs of a still-evolving First Amendment doctrine."76 Because that "framework can accommodate the protection sought by all but the most zealous champions of expression plausibly denominated as commercial speech," it substantiates "the affirmative value of this imperfectly defined category of expression."77 Vladeck's more recent assessment holds that the "basic truth about the commercial speech doctrine is that it was crafted as a pragmatic solution to the complicated problem of how to open the door to truthful communications between sellers and prospective purchasers while continuing to shield prospective purchasers from falsehoods and half-truths that distort the market."78 While the 
Central Hudson test has "not served that goal perfectly," it has served it well enough that "the doctrine is criticized far more for its theoretical failings than for the results it produces, ... [which] have been generally predictable and broadly approved." 79

Schauer proposed that the effectiveness of the Hudson-centric doctrine is grounded in a deeper truth that rejects arguments based on fallacious notions that "a distinction that cannot be sharply drawn cannot be drawn at all," a contention that "betrays most of our linguistic life, a life in which we readily distinguish night from day, frogs from tadpoles, short from tall, fat from thin, old from young, and rich from poor without feeling that the lack of a clear line of demarcation ... renders the distinction incoherent." 80 While readily conceding "that the processes of talking and of adjudication are different," he insisted that "once we see that difficulties in drawing lines are not an insuperable barrier to the intelligibility of a distinction, we see that a major task in the legal system is to manage the effects of fuzzy lines, rather than to take the existence of a fuzzy line as a sign that something is foundationally amiss." 81

While Schauer argued for maintaining a distinction that may not always "be sharply drawn" in order to preserve the more vital informational "core of the First Amendment," 82 Tushnet made the case for how failure to do so would undermine the contractual end of the balance. She maintains that abandoning "the difficult line-drawing problems that the commercial speech doctrine creates" would weaken "the consumer protection objectives served by modern commercial speech regulation" because other causes of action, such as fraud, would be less effective in protecting consumers. ${ }^{83}$ As Sherry's analysis of the Rehnquist Court's broader jurisprudence (which in the most essential respects relied upon the doctrine of the Powell Era Court in its First Amendment cases on advertising) concluded: "[R]egulation of commercial speech raises genuinely difficult questions that cannot be answered by mechanical recourse to ideology, theory, or first principles." 84 She found it "therefore laudable that the Court has, by and large, not attempted such a synthesis, but has rather approached each case in a pragmatist, common-law fashion, building up a body of guiding (but not rigidly constraining) precedent." 85

Still further support for this monograph's assessment of the Hudsoncentric commercial speech doctrine and its maintenance of the intermediate-level status of commercial speech as philosophically consistent with historically grounded principles of sound business law, experience, and practice can be drawn from the business-oriented dispositions of many of the justices who established the fundamental contours of that doctrine. The Supreme Court had been dramatically reconfigured at the beginning of the seventies, after President Nixon appointed four new justices between 1969 and 1972, including Chief Justice Warren E. Burger and Justices Blackmun, Powell, and Rehnquist. "[O]n the crucial issues, the Nixon Justices could be expected, more often than not, to end up on the same side," Justice Powell's biographer wrote. "Each of them was more conservative than any of the holdovers from the Warren Court. Together they formed a block of four, 
loosely united by outlook and sympathy, and — apparently — poised under the leadership of Chief Justice Burger to remake American constitutional law." ${ }^{86}$ Indeed, with regard to "economic freedom under the antitrust laws, ... the work of the Burger Court" would prove "little less than revolutionary $\ldots$ and the result almost always was to increase business freedom and reduce antitrust liability." 87

Not all the justices on the Court during that period had business connections in their background, but several did. Even Justice William O. Douglas, more often identified with his long career on the Warren Court, "did not enter into his Court duties as a civil libertarian or environmentalist but as a corporate financial expert" from the faculty of Yale Law School and the Securities and Exchange Commission. ${ }^{88}$ As the chairman of the SEC, he "succeeded in establishing cooperative relationships with the financial community and persuaded it to undertake most of the work of reforming itself, with minimal government involvement." ${ }^{89}$ Justice William J. Brennan had a degree from the Wharton School of Finance and Commerce at the University of Pennsylvania. ${ }^{90}$ Justice Potter Stewart had a successful career in corporate law in Cincinnati before joining the Court. ${ }^{91}$ Justice Blackmun had specialized in tax and estates work as senior partner at a Minneapolis law firm. ${ }^{92}$

\section{Justice Powell's Deep Grounding in American Business Practice}

Beyond any doubt though, it was Justice Lewis F. Powell, Jr. who arrived at the Court most deeply grounded in the practices of American business - indeed, arguably more so than any justice since. "Powell's nearly forty years of experience in corporate boardrooms led him to trust the character of the average American businessman," Pritchard wrote of the long, successful career in corporate law that continued until his Supreme Court appointment. "In Powell's world, free enterprise and the businessmen who made it work were the foundation of strong communities." ${ }^{93}$ So extensive were his business connections that before his confirmation to the Court, he had worried that his deep and extensive associations in corporate circles would generate the sort of controversy that contributed to the rejection of Nixon nominee Clement Haynsworth two years before. He feared that "the nomination of another southern lawyer with a business-oriented background would invite - if not assure - organized and perhaps prolonged opposition." 94

The confirmation hearings went relatively smoothly, however, and once on the Court, Justice Powell's business orientation was unmistakable. In regard to disclosures imposed upon publicly owned companies by government, for example, Pritchard found that "it would be difficult to identify anyone who did more to limit the reach of the federal securities law than Powell." "95 Pritchard found that, while acting "in all good faith," Justice Powell assessed such requirements in a manner "colored by his experience in corporate boardrooms, consistently leading him to favor narrower read- 
ings."96 In other research, Pritchard concluded that during his years at the Supreme Court, Justice Powell successfully worked to restrain prosecutions for insider trading. ${ }^{97}$ More importantly, research documented the ways in which corporate interests have won ever-greater Bill of Rights guarantees, particularly since the early seventies. ${ }^{98} \mathrm{~A}$ number of cases in which Justice Powell participated can be seen as part of that process, particularly his efforts advancing First Amendment protection for commercial speech. ${ }^{99}$

Shortly after Justice Powell joined the Supreme Court, a document became public that detailed just how extraordinary was the extent of his concerns with advancing interests of the business community. As The New York Times reported it in September of 1972, "Lewis F. Powell, Jr., in a confidential memorandum written two months before his nomination to the Supreme Court, urged the United States Chamber of Commerce to mount a campaign to counter criticism of the free enterprise system in the schools and the news media." 100 The Chamber later distributed the memorandum to its national membership in a 1971 newsletter under the headline "Attack on American Free Enterprise System." Its recommendations included the mounting of aggressive efforts in schools, media and the courts - particularly the Supreme Court - to advance business interests through the initiation of litigation and the filing of amici briefs. "[E]specially with an activistminded Supreme Court," it declared, "the judiciary may be the most important instrument for social, economic and political change. ${ }^{101}$

The memorandum maintained "[f]ew elements of American society today have as little influence in government as the American businessman, the corporation, or even the millions of corporate stockholders." 102 It called for corporations to counter the "disquieting voices ... of criticism" by waging through advertising and other public discourse "a sustained, major effort to inform and enlighten the American people," not only separately but also with a level of coordination beyond any ever mounted at that time. ${ }^{103 " S t r e n g t h ~ l i e s ~ i n ~ o r g a n i z a t i o n, ~ i n ~ c a r e f u l ~ l o n g-r a n g e ~ p l a n n i n g ~ a n d ~}$ implementation, in consistency of action over an indefinite period of years, in the scale of financing available only through joint effort, and in the political power available only through united action and national organizations," the memorandum declared. ${ }^{104}$ At the same time it urged the business community to speak out more freely, it also called for maintaining an emphasis on truth and broader societal concern in the informational efforts: "Essential ingredients of the entire program must be responsibility.... The publications, the articles, the speeches, the media programs, the advertising ... must meet the most exacting standards of accuracy and professional excellence. They must merit respect for their level of public responsibility."105 While "[n]ot all businessmen shared Powell's passions," historian Kim Phillips-Fein has concluded, "those who did began to act as a vanguard organizing the giants of American industry."106

Justice Powell would go on - particularly in the commercial speech cases - to demonstrate a greater priority on balancing among societal interests than on ideologically advantaging business interests over all others. However, his appointment to the Supreme Court — as the "author of a sem- 
inal report to the U.S. Chamber of Commerce calling for counter-mobilization against public interest lawyers" - has been described by Steven Teles as a telling example of a reaction by many conservative lawyers and business leaders against earlier successes of public interest law or "legal liberalism."107 Teles characterizes the memorandum as "the most notorious indication of business's early strategic response to legal liberalism."108 Ann Southworth also detailed how the "counterattack" began "soon after the release of the Powell memorandum," quickly fulfilling not only his contemplation that "the U.S. Chamber of Commerce would become the primary representative of American business in the courts and agencies" but also the even more rapid creation of a number of "conservative public interest law organizations" supported by foundations and business. ${ }^{109}$

Justice Ruth Bader Ginsburg on more than one occasion has commented publicly on the striking influence of the memorandum on legal activism by business interests, declaring, for example that it "advised the business community to adopt the 'astute' ways of activist liberals 'in exploiting judicial action.' The briefs that currently troop before the Supreme Court, from all manner of organizations, suggest that Powell's message has been heard."110 Recent analysis by legal scholar Jeffrey Rosen has linked the success of the memorandum's call for "creating a network of activist conservative litigation groups" with the growing strength of the "Constitution in Exile” movement. Such efforts actively promote litigation aimed at advancing a doctrine of "economic rights" that would roll back government regulation to early twentieth-century standards. ${ }^{111}$ That period is often called the "Lochner Era" in reference to the New York v. Lochner"112 ruling that struck down a New York regulation limiting to sixty the number of hours that bakery employees could be required to work in a week and for more than three decades provided broad precedent for invalidating other regulation of business, until its holding was rejected by the Court in West Coast Hotel Co. v. Parrish. ${ }^{113}$

The era in which the "Attack on American Free Enterprise System" memorandum was first circulated has been documented as one shaped by the historical dynamics of a backlash from big business in response to a wave of successes by consumer and environmental movements in the late 1969s and early 1970s. ${ }^{114}$ According to Lee Edwards, official historian of the Heritage Foundation, beer magnate Joseph Coors, Sr. said the "Attack on American Free Enterprise System" memorandum convinced him that American business was "ignoring a crisis," which led him in 1971 to invest the first $\$ 250,000$ to fund what later became the Heritage Foundation. ${ }^{115}$ Such synergy between business interests and the political movement that has come to be known as modern conservatism began to reach critical mass in the 1970s. ${ }^{116}$ Many of the nation's wealthiest business executives began to generously subsidize think tanks, journals, and other media activities that served to more widely promote the work of economists who favored a diminished role for government regulation. ${ }^{117}$ Phillips-Fein traced how decades of work by determined business leaders "supported and helped to formulate the economic agenda of the conservative movement" that grew 
most publicly manifest with the rise of Ronald Reagan to national political prominence over the course of that decade. ${ }^{118}$ The process through which Reagan's core themes and rhetoric were significantly shaped by his years as a popular corporate spokesperson for General Electric after his career in the movies ended has been detailed by Thomas Evans:119 "Much of this came from the policies of the company he worked for and the role that company chose to play in the politics of the nation," he wrote. ${ }^{120}$ Phillips-Fein devotes a chapter to the way the "Attack" memorandum "crystallized a set of concerns shared by business conservatives in the early 1970s."121 Other recent works on political developments of the period have credited the memorandum with motivating greater levels of political activity on behalf of the modern conservative movement by the business community in the era, both through financial support and media efforts. ${ }^{122}$

Phillips-Fein notes that Justice Powell ceased his work with the Chamber of Commerce after joining the Court, but before then he provided copies of his memorandum to friends in the business community and urged greater activism of the sort the memorandum advocated. ${ }^{123}$ Those contacts included general counsel at General Motors, and a few months later, in a New York Times op-ed column, General Motors Chief Executive Officer R.C. Gerstenberg called for greater influence by business interests in the marketplace of ideas. "Recent experience teaches us that the importance of public opinion should never be underestimated, that legislation follows opinion, and uninformed opinion can lead to bad legislation and to unreasonable controls and restraints by government," he wrote. "The business community has a job to do.... Individually and collectively, we must speak out more than we have."124

In scholarly literature, the "Attack on American Free Enterprise System" memorandum has been characterized as highly influential in a number of contexts, but most broadly as the inspiration for a broad, probusiness political movement. Houck declared that in the Powell memorandum, "the concept for a business-interest litigation center was born," beginning with a study based on the memorandum by the California Chamber of Commerce, which resulted in creation of the Pacific Legal Foundation in 1973. ${ }^{125}$ Foden labeled the wave of similar organizations that soon followed "the Freedom Based Public Interest Movement" and also traced their inspiration to the Powell memorandum's call for "the creation of conservative public interest groups to defend the business community in the courts."126 Bogus characterized the Powell memorandum's vision as "realized more quickly and effectively than he could have imagined," including the beginning of successful "tort reform" campaigns "designed to shield big business and medicine from citizen lawsuits." ${ }^{27}$ Plater has discussed the role that the memorandum's call "for business to begin funding academic and representational programs and foundations to counteract the 1960s ideologies in American society" played in successful efforts to block environmental regulation. ${ }^{128}$ Franklin has linked the U.S. Chamber of Commerce's highly successful efforts at the Supreme Court in recent years - winning almost seventy percent of cases in which it filed a brief either as a party in litigation 
or as an amicus the first three terms of the Roberts Court and sixty-two percent during the previous eleven terms of the Rehnquist Court - to the litigation practices launched in response to Powell's memorandum. ${ }^{129}$

Many historical assessments of the period have credited the memorandum with motivating greater levels of political activity by the business community. ${ }^{130}$ Certainly, the 1970 s were characterized by such efforts. The year after the "Attack on American Free Enterprise System" memorandum was distributed to Chamber members, some 200 chief executive officers from the nation's largest corporations formed the Business Roundtable in order to establish a unified political voice representing their diverse business interests. By the middle of the decade it was being characterized in the business press as "the most powerful voice of business in Washington." 131 The period also saw the introduction of the groundbreaking advocacy strategy that would make Mobil Oil the most prominent corporate voice of the time by purchasing space on The New York Times op-ed page far more regularly than any other company had at that time. ${ }^{132}$ It proved so successful that political scientist Walter Berns titled an essay he published at the end of the decade "The Corporation's Song: Book and Lyrics by Hobbes, Locke, and Madison. Music by Mobil Oil?"133 Research has documented a process through which the business community dramatically overhauled its manner of engaging the legislative process over the course of the seventies. ${ }^{134}$ Edsall's history of the era found that "the political stature of business rose steadily from the early 1970s, one of its lowest points in the nation's history, until, by the end of the decade, the business community had achieved virtual dominance of the legislative process in Congress." 135

Given the influence of Justice Powell's "Attack on American Free Enterprise System” memorandum in such significant historical developments and his similarly considerable influence in a series of First Amendment cases involving business interests at the Supreme Court over the same period, this study finds it useful to focus upon his private papers for insight into related jurisprudence. Indeed, in the context of this study's analysis, it is historically justifiable and more precise to discuss the work at the Court during those years that produced the formative body of modern First Amendment commercial speech jurisprudence under the rubric of the "Powell Era Court." Eras at the High Court are more commonly bracketed in terms of the Chief Justice in office at the time, and by that measure it is the Burger Court that spans the years from 1969 to 1986, when Chief Justice Burger was presiding. This monograph's focus is more specifically on the subset of cases falling within that period at the Court through which its doctrine on commercial speech was dramatically transformed. Certainly other justices played important roles in that process, including of course Chief Justice Burger. Yet in the context of those formative commercial speech cases as a whole and the doctrinally defining impact of Central Hudson Gas and Electric. v. Public Service Commission, ${ }^{136}$ it is Justice Powell whose influence endured most substantially. The next section considers his efforts in shaping those cases and in particular his work in successfully authoring an opinion in Central Hudson that would be carefully balanced enough to 
meet the manifold concerns of a majority of the justices.

\section{Commercial Speech and the Powell Era Court}

Close examination of Justice Powell's work in the Supreme Court's formative commercial speech cases reveals a high degree of consistency. Cases presenting First Amendment questions involving advertising began to arrive at the Court at the beginning of his time there, and continued to do so almost every year he remained on the bench. Justice Powell's private papers indicate that from the start he favored a shift away from the earlier doctrine in which commercial speech received no First Amendment protection. However, at the same time - in contrast to the tone of much of the ideologically imbalanced discourse and political activity that his "Attack" memorandum seems to have helped foster - Justice Powell consistently emphasized significant concerns over the potential for totally unregulated advertising to undermine the fair-bargaining process. He would maintain those concerns in his jurisprudence consistently over the years and would successfully institutionalize a structural balancing of them in his Central Hudson opinion. ${ }^{137}$

For most of Justice Powell's career in law, advertising had been deemed a form of expression outside the parameters of First Amendment protection. In 1942, the Supreme Court had responded almost dismissively when it addressed the matter in Valentine v. Chrestensen, declaring in a unanimously four-page opinion that a "purely commercial advertisement" merited no such protection from government regulation. ${ }^{138}$ The potential for a shift away from that position, however, had been signaled in 1964 when the Court qualified its sweeping Chrestensen pronouncement in the course of reaching the landmark ruling that constitutionalized libel law in New York Times v. Sullivan. ${ }^{139}$ The ruling acknowledged that the facts of that case demonstrated advertising format alone could not bar the speech involved from First Amendment protection. ${ }^{140}$ The Court held firm on its commercial speech doctrine more broadly though by sharply distinguishing the Sullivan context from that of Chrestensen. It emphasized that the latter amounted to an effort "to evade" an ordinance regulating handbills in order to promote a commercial venture, while Sullivan's purpose was advancing the cause of "a movement whose existence and objectives are matters of the highest public interest and concern." 141 Nevertheless, Sullivan offered an opening for cases that worked their way toward the Court and would determine how far First Amendment protection for advertising might be extended.

Justice Powell authored his first opinion on the subject shortly after joining the Court in 1973's Pittsburgh Press Co. v. Pittsburgh Commission on Human Relations, which he declared early in the proceedings to be "very close." 142 The newspaper that brought the case challenged a city regulation barring help-wanted advertisements segregated according to male or female interest. It asked the Court to "abrogate the distinction between commercial and other speech." ${ }^{143}$ At conference, the justices were, as Powell predicted, closely divided, according to Justice his notes. ${ }^{144}$ He wrote that three of his brethren (Justices Douglas, Blackmun, and Stewart) were essentially ready 
to rule as the appellants had urged - although their concern at that time seemed to be more with freedom of the press than with protecting commercial speech per se. ${ }^{145}$ Justice Douglas, for example, according to Powell, declared that the "press is free to do what it wants regardless of any distinction between commercial and editorial matter."146

A majority of the justices, however, were opposed to going that direction. Justice Marshall asserted that the "distinction between commercial and editorial matter" made the decision "very simple, clear cut." Justice Brennan argued that the regulation did not actually restrict content and thus was justified by the government's interest in preventing sex discrimination. ${ }^{147}$ Justice Powell wrote that although he leaned toward upholding the regulation, he did not find the matter as easily resolved as Justices Marshall and Brennan and expressed concern over the Court reaching what he viewed the correct result via an incorrect analysis. ${ }^{148}$ In his own notes where he sought to work through the competing interests, Justice Powell stressed that he hoped for a rationale that would avoid an imbalance in the ruling's precedent value by favoring “"press' rights over 'free speech”, or by punishing the press for publishing such advertisements. ${ }^{149}$

Ultimately the Court would split five-to-four and reject the newspaper's argument. Justice Powell's majority opinion concluded that "[i]n the crucial respects, the advertisements in the present record resemble the Chrestensen rather than the Sullivan advertisement." According to his analysis, the helpwanted ads did not express a position on "whether, as a matter of social policy, certain positions ought to be filled by members of one or the other sex, nor does any of them criticize the Ordinance or the Commission's enforcement practices. Each is no more than a proposal of possible employment. The advertisements are thus classic examples of commercial speech." Justice Powell's opinion indicated how unwilling he was to consider commercial speech in need of First Amendment protection. He declared, for example, that the profit motive of advertising could not by itself justify such subordination: "If a newspaper's profit motive were determinative, all aspects of its operations - from the selection of news stories to the choice of editorial position - would be subject to regulation if it could be established that they were conducted with a view toward increased sales. Such a basis for regulation clearly would be incompatible with the First Amendment."150

Nevertheless, the facts of Pittsburgh Press were insufficient to persuade the Court "that either the decision to accept a commercial advertisement which the advertiser directs to be placed in a sex-designated column or the actual placement there lifts the newspaper's actions from the category of commercial speech." 151 Neither did those facts justify affording commercial speech "a higher level of protection than Chrestensen and its progeny would suggest" or - as the newspaper had argued for - abrogating "the distinction between commercial and other speech."152 Essentially, Justice Powell and the Pittsburgh Press Court chose to focus the ruling more on the specific nature of the contractual elements of commercial expression involved, rather than on the element of informational freedom. 
"Discrimination in employment is not only commercial activity, it is illegal commercial activity under the Ordinance," he wrote in the majority opinion. ${ }^{153}$ Thus, speech that involved illegal activity could not be justified as preserving elements of the fair-bargaining process within the scope of transactional promises between seller and buyer: "Any First Amendment interest which might be served by advertising an ordinary commercial proposal and which might arguably outweigh the governmental interest supporting the regulation is altogether absent when the commercial activity itself is illegal and the restriction on advertising is incidental to a valid limitation on economic activity." 154

The next year offered further evidence of how closely the Court was divided in its efforts to arrive at the appropriate balance on First Amendment protection for commercial speech when the Court considered the constitutionality of a ban on political advertising on city buses in Lehman v. City of Shaker Heights. ${ }^{155}$ Five justices supported the judgment upholding the ban, but they could not agree on a majority opinion. The plurality opinion by Justice Blackmun and the dissent by Justice Brennan each were joined by four justices. ${ }^{156}$ The plurality opinion focused on its assertion that since buses did not constitute a public forum for First Amendment purposes, the city was free to allow commercial advertising on cards posted inside the buses while not accepting political advertising. Justice Blackmun wrote, "Here, we have no open spaces, no meeting hall, park, street corner, or other public thoroughfare. Instead, the city is engaged in commerce" in providing bus service. ${ }^{157}$

"In much the same way that a newspaper or periodical, or even a radio or television station, need not accept every proffer of advertising from the general public," his opinion declared, "a city transit system has discretion to develop and make reasonable choices concerning the type of advertising that may be displayed in its vehicles." 158 Although the First Amendment bars government from making choices on an "arbitrary, capricious, or invidious" basis, in the assessment of the Court, the city in Lehman had not done so. Here, the city had chosen to avoid "sticky administrative problems [that] might arise in parceling out limited space to eager politicians."159 Thus, the decision to limit advertising within city buses to "innocuous and less controversial commercial and service oriented advertising" did not violate the First Amendment, Justice Blackmun wrote. "Were we to hold to the contrary, display cases in public hospitals, libraries, office buildings, military compounds, and other public facilities immediately would become Hyde Parks open to every would-be pamphleteer and politician. This the Constitution does not require."160

The dissent by Justice Brennan argued that by "accepting commercial and public service advertising [inside its buses], the city effectively waived any argument" that advertising was "incompatible with the rapid transit system's primary function of providing transportation. A forum for communication was voluntarily established when the city installed the physical facilities for the advertisements." 161 Conceding that it was "possible that commercial advertising may be accorded less First Amendment protection 
than speech concerning political and social issues of public importance," Justice Brennan maintained nevertheless that to "sanction the city's preference for bland commercialism and noncontroversial public service messages" over political expression serves to "reverse the traditional priorities of the First Amendment."162 Justice Powell joined that dissent. He expressed willingness at conference to accept regulation of excessively intrusive advertising, but argued that print messages on city buses could not be so classified. ${ }^{163}$ In a blunt passage in his own notes that vividly conveyed his own position on the matter, he asked rhetorically what justified classifying political advertisements as more intrusive than commercial messages: "Is this worse than Kotex or ads for hemorrhoid relief?"164

Despite the Court's differences in that case, the justices would reach much greater consensus a year later and offer the clearest signal to date of their willingness to extend First Amendment protections for commercial speech considerably farther than ever before. At conference in Bigelow $v$. Commonwealth of Virginia, ${ }^{165}$ seven justices were already in agreement with a lower court ruling that denied a challenge to a ban on advertising even legal abortion services that was then in place in Virginia. ${ }^{166}$ Despite the general agreement among the justices for the essential judgment that should be reached, Justice Powell noted early on, "I doubt this is a good vehicle to consider the First Amendment issue." Since the lower-court ruling, the ban had been amended to apply only to advertising that promoted abortions a violation of Virginia law. ${ }^{167}$

In a subsequent ruling that reversed the conviction of a newspaper publisher for advertising the legal availability of abortion services in New York, ${ }^{168}$ the seven-to-two majority, as in Bigelow argued that the case had limited First Amendment application. Justice Blackmun's opinion ostensibly left Chrestensen's essential holding intact but declared it "distinctly a limited one" and did not provide "authority for the proposition that all statutes regulating commercial advertising are immune from constitutional challenge."169 The Court found that the advertisement in Bigelow "conveyed information of potential interest and value" that was protected, but refrained from actually going further at that point: "We need not decide in this case the precise extent to which the First Amendment permits regulation of advertising that is related to activities the State may legitimately regulate or even prohibit." 170

By the next year, the Court was ready to take that step with a case in which the commercial messages at issue involved none of the political or social implications that had complicated the recent advertising cases. In 1976's Virginia State Board of Pharmacy v. Virginia Citizens Consumer Council, ${ }^{171}$ the Court took the opportunity to hand down the landmark ruling that established First Amendment protection for speech "which does "no more than propose a commercial transaction." In that case the issue was the advertising of prescription drug prices. ${ }^{172}$ In striking down a state statute banning such advertising by pharmacists, ${ }^{173}$ a seven-justice majority emphasized the restraint that the First Amendment places on government against denying truthful information to citizens: "Virginia is free to require 
whatever professional standards it wishes of its pharmacists... But it may not do so by keeping the public in ignorance of the entirely lawful terms that competing pharmacists are offering." 174

Justice Blackmun's majority opinion upheld the notion that the public good is served when consumers receive accurate commercial information: "So long as we preserve a predominantly free enterprise economy, the allocation of our resources in large measure will be made through numerous private economic decisions. It is a matter of public interest that those decisions, in the aggregate, be intelligent and well informed. To this end, the free flow of commercial information is indispensable." 175 Yet even in making that statement of broad support for the freedom of the informational component of advertising, the Court made note of maintaining a doctrinal balance through preservation of the fair-bargaining process implicated in the contractual component of such speech. "The First Amendment ... does not prohibit the State from insuring that the stream of commercial information flow cleanly as well as freely," Justice Blackmun wrote. ${ }^{176}$ He added that in "concluding that commercial speech enjoys First Amendment protection, we have not held that it is wholly undifferentiable from other forms.... Even if the differences do not justify the conclusion that commercial speech is valueless, and thus subject to complete suppression by the State, they nonetheless suggest that a different degree of protection is necessary to insure that the flow of truthful and legitimate commercial information is unimpaired." 177

To bolster that assertion, Justice Stewart authored a concurring opinion that detailed how established principles from First Amendment law "suggest that government may take broader action to protect the public from injury produced by false or deceptive price or product advertising." 178 Justice Stewart emphasized that the Court had "on several occasions," made clear that "the Constitution does not provide absolute protection for false factual statements that cause private injury." 179 In analysis that focused on the reality of how the contractual component of commercial speech created for it a stark contrast from press expression, Justice Stewart pointed out that while the press "must often attempt to assemble the true facts from sketchy and sometimes conflicting sources under the pressure of publication deadlines, the commercial advertiser generally knows the product or service he seeks to sell and is in a position to verify the accuracy of his factual representations before he disseminates them." 180 Because the "advertiser's access to the truth about his product and its price substantially eliminates any danger that governmental regulation of false or misleading price or product advertising will chill accurate and nondeceptive commercial expression," he declared, there is less justification for sanctioning falsehood in commercial speech. ${ }^{181}$

Indeed, Justice Stewart elaborated at some length on the inherent dualistic informational/contractual nature of commercial speech and how those components must be balanced in First Amendment doctrine: "Commercial price and product advertising differs markedly from ideological expression because it is confined to the promotion of specific goods or services."182 The 
First Amendment protects advertising "because of the "information of potential interest and value' conveyed," not "because of any direct contribution to the interchange of ideas," he stressed. ${ }^{183}$ The "factual claims contained in commercial price or product advertisements relate to tangible goods or services" and "may be tested empirically and corrected to reflect the truth without in any manner jeopardizing the free dissemination of thought," he wrote, and therefore, "the elimination of false and deceptive claims serves to promote the one facet of commercial price and product advertising that warrants First Amendment protection - its contribution to the flow of accurate and reliable information relevant to public and private decisionmaking." 184

Justice Powell was also deeply involved in attempting to shape the ruling along lines he felt would most effectively contribute to the balancing effort that characterized the majority opinion. Early in his consideration of the case, he noted that although he perceived "no legitimate state interest that is furthered by a prohibition against advertising the prices of prescription drugs," he believed the question before the Court should be addressed through an analysis "under which First Amendment interests are balanced against the state's interest in the regulation." 185 He noted after oral arguments that the ruling should be grounded in "a derivative right to receive communication" but "should make clear" the First Amendment "doesn't preclude regulation of false or misleading advertising." ${ }^{186}$ His papers indicate that he had decided early regarding the judgment but that he wrestled longer with what he felt would be the best way to express constitutional support for commercial speech in terms that did not sweep aside "the state interest in protecting professional standards" or allow unlimited "advertising by lawyers, doctors, and other professionals."187

Upon reviewing a draft of Justice Blackmun's majority opinion that Justice Powell felt could "prevent a discriminating assessment — and balancing — of the public interest against the First Amendment rights when we have the medical and legal professions before us," he wrote to request addition of a passage that would emphasize: "Doctors and lawyers, for example, do not dispense standardized products; they render professional services of almost infinite variety and nature, with the consequent enhanced opportunity for confusion and deception if they were to undertake certain kinds of advertising." 188

After Justice Brennan suggested avoiding use of the word "opportunity" in that manner, which he felt connoted "ambulance chasers,"189 Justice Blackmun arrived at a more tactful phrasing that persuaded Justice Powell to join the opinion. "We stress that we have considered in this case the regulation of commercial advertising by pharmacists. Although we express no opinion as to other professions, the distinctions, historical and functional, between professions, may require consideration of quite different factors," Blackmun wrote. "Physicians and lawyers, for example, do not dispense standardized products; they render professional services of almost infinite variety and nature, with the consequent enhanced possibility for confusion and deception if they were to undertake certain kinds of advertising."190 
Chief Justice Burger also authored a concurring opinion that set out the "quite different factors [that] would govern were we faced with a law regulating or even prohibiting advertising by the traditional learned professions of medicine or law."191

Justice Powell was relatively less invested in shaping 1977's Linmark Associates, Inc. v. Township of Willingboro ${ }^{192}$ in which he joined the majority holding that declared unconstitutional a city ban on the posting of signs advertising homes for sale, finding "no meaningful distinction between" it and "the statute overturned in Virginia Pharmacy." "193 The ordinance was intended to promote racial integration by preventing " "panic selling' ... by whites who feared that the township was becoming all black, and that property values would decline."194 In his notes from the justices' conference on the case, Powell indicated that he found it an "[e]xtremely close case" to which he "probably would not dissent - either way." After Virginia Pharmacy, he believed there were limits on commercial speech and that the city's interest justifying the regulation in Linmark Associates was "very strong."195

The majority opinion by Justice Marshall focused on the Court's conclusion that the challenged regulation "acted to prevent its residents from obtaining certain information," information "of vital interest" to residents, considering its bearing on their decisions on "where to live and raise their families." 196 The city council had "sought to restrict the free flow of these data" because it feared that otherwise homeowners would "make decisions inimical to what the Council views as the homeowners,", decisions "to leave town," Justice Marshall wrote. ${ }^{197}$ Thus the government's concern was "not with any commercial aspect of 'For Sale' signs ... but with the substance of the information communicated to Willingboro citizens. If dissemination of this information can be restricted, then every locality in the country can suppress any facts that reflect poorly on the locality." 198 Denying government "such sweeping powers" was precisely what Virginia Pharmacy was all about, Justice Marshall emphasized, in that it firmly rejected any claim by government that "the only way it could enable its citizens to find their self-interest was to deny them information that is neither false nor misleading." 199

Justice Powell joined in much more vigorously the next year upon discovering in Bates v. State Bar of Arizona ${ }^{200}$ that despite his earlier efforts to wall off Virginia Pharmacy from its holding being extended to advertising by physicians and lawyers, a majority of his brethren found insufficient basis to justify a total ban on advertising by attorneys. ${ }^{201}$ "The choice between the dangers of suppressing information and the dangers arising from its free flow was seen as precisely the choice 'that the First Amendment makes for us,"” Justice Blackmun's majority opinion said of Virginia Pharmacy. "Like the Virginia statutes, the disciplinary rule serves to inhibit the free flow of commercial information and to keep the public in ignorance."202 Thus, the majority concluded that what was in question in Bates was "whether the State may prevent the publication ... [of] truthful advertisement concerning the availability and terms of routine legal servic- 
es," and that it must "rule simply that the flow of such information may not be restrained." ${ }^{203}$ Nevertheless, it also reinforced the intrinsic relationship of the informational/contractual balance to the First Amendment protection accorded to commercial expression. Because "the public and private benefits from commercial speech derive from confidence in its accuracy and reliability," Justice Blackmun wrote, "the leeway for untruthful or misleading expression that has been allowed in other contexts has little force in the commercial arena."204

Justice Powell's papers indicate, however, that he felt the greater thrust of the ruling potentially represented an unjustified imbalancing in commercial speech jurisprudence. After oral arguments he noted that "most lawyer ads would be inherently deceptive if price for services" were allowed to be advertised, and even though he found "[t]his particular ad is close. On balance I think it is likely to mislead." ${ }^{205}$ When he reviewed Justice Blackmun's draft opinion himself, Justice Powell politely rejected his clerk's analysis of it: "Good memo. I'll not buy a good deal of it." ${ }^{206}$ He made extensive notes of his own on the draft opinion ${ }^{207}$ and developed a substantial dissent. ${ }^{208} \mathrm{He}$ concurred with the part of the majority holding that rejected an antitrust claim by the appellants but refused to "join the Court's holding that under the First Amendment 'truthful' newspaper advertising of a lawyer's prices for 'routine legal services' may not be restrained." 209

He insisted that the holding was too "explicit and expansive with respect to the advertising of undefined 'routine legal services' a result "neither required by the First Amendment, nor in the public interest." ${ }^{210}$ Powell contended that "there simply is no way to test 'empirically' the claims made in" much advertising of legal services because of "serious difficulties in determining whether the advertised services fall within the Court's undefined category of 'routine services.",211 “These are not factual questions for which there are 'truthful' answers," he maintained, because "in most instances, the answers would turn on relatively subjective judgments as to which there could be wide differences of opinion." "212

In 1978, Justice Powell wrote that he saw "Bates' chickens coming home to roost!" 213 in Ohralik v. Ohio State Bar Association. ${ }^{214}$ The case involved a First Amendment challenge to sanctions against an attorney who had induced two 18-year-old women, one of whom was lying in traction in a hospital bed to hire him to recover damages after an automobile accident. ${ }^{215}$ In doing so he utilized tactics that involved undue influence, overreaching, and misrepresentation to a degree that Justice Marshall characterized them as "classic examples of 'ambulance chasing." 216 The Court seemed to agree with Justice Powell that some degree of balancing was in order from its ruling in Bates just the year before. Five other justices joined his majority opinion and its judgment that government "constitutionally may discipline a lawyer for soliciting clients in person, for pecuniary gain, under circumstances likely to pose dangers that the State has a right to prevent" received unanimous backing. ${ }^{217}$ Justice Blackmun called the majority opinion "a good middle-of-the-road opinion that resolves this case and lends at least some guidance for the future." 218 
"The solicitation of business by a lawyer through direct, in-person communication with the prospective client has long been viewed as inconsistent with the profession's ideal of the attorney-client relationship and as posing a significant potential for harm to the prospective client," Justice Powell wrote. "It has been proscribed by the organized Bar for many years.... The entitlement of in-person solicitation of clients to the protection of the First Amendment differs from that of the kind of advertising approved in Bates, as does the strength of the State's countervailing interest in prohibition." 219 In refusing to provide First Amendment protection to that form of advertising, Justice Powell's opinion clearly reasserted his belief that " $\mathrm{t}]_{\mathrm{o}}$ require a parity of constitutional protection for commercial and noncommercial speech alike could invite dilution, simply by a leveling process, of the force of the Amendment's guarantee with respect to the latter kind of speech." ${ }^{220} \mathrm{He}$ declared that in-person "solicitation of professional employment by a lawyer does not stand on a par with truthful advertising about the availability and terms of routine legal services, let alone with forms of speech more traditionally within the concern of the First Amendment." 221

Powell continued to firmly advance that assertion in 1979's Friedman v. Rogers ${ }^{222}$ indicating early in the Court's consideration of the case that it should not extend First Amendment protection to trade names, as the lower court had in Friedman. ${ }^{223}$ "[A] trade name is not speech," he insisted, because it "is a property interest" rather than a First Amendment right and "conveys no information intrinsically — only by association." ${ }^{224}$ According to Powell's notes, there was wide agreement among the justices on that at conference. Justice Stevens asserted, "We must contain" the commercial speech doctrine, limiting "our cases to situations where [the] purpose is to convey truthful information.”225 Similarly, Justice Stewart underscored at conference: "Truth was emphasized" in the previous commercial speech cases. "This statute is intended to promote full disclosure." 226

Ultimately, Justice Powell authored a majority opinion that sharply distinguished economic regulation of property interests such as trade names from regulation of protected forms of expression. ${ }^{227}$ In doing so, he provided further articulation of the contrasting functions of informational and contractual expression. "A trade name that has acquired such associations to the extent of establishing a secondary meaning becomes a valuable property of the business, protected from appropriation by others," he wrote. "But a property interest in a means of communication does not enlarge or diminish the First Amendment protection of that communication. Accordingly, there is no First Amendment rule ... requiring a State to allow deceptive or misleading commercial speech whenever the publication of additional information can clarify or offset the effects of the spurious communication," Justice Powell pronounced. "There is no claim in this case that Rogers or other optometrists practicing under trade names have been deprived of property without due process of law, or indeed that their property has been taken at all."228

Thus, a series of commercial speech cases had set the stage by the end of the decade for Central Hudson Gas and Electric v. Public Service 
Commission. ${ }^{229}$ The Powell Era Court had firmly distanced the jurisprudence from the earlier doctrine that left advertising beyond the scope of First Amendment protections. Yet it had just as clearly demonstrated its commitment to balancing the interests of sellers' informational speech against the interests of buyers to be protected from deceptive expression that would undermine the fair-bargaining process.

\section{Centering the Doctrine on Central Hudson}

In Central Hudson, which involved a First Amendment challenge to a New York ban on any advertising that promoted the use of electricity, Justice Powell led the Court more resolutely and made his most enduring contribution to the modern commercial speech doctrine. What would institutionalize the ruling's importance would be the standardized, four-part test $^{230}$ that he developed for determining whether a government regulation of advertising challenged on First Amendment grounds could withstand an intermediate level of scrutiny. ${ }^{231}$ As Powell developed the Hudson test, the clerk who assisted him with the case observed that the "first commercial speech cases could not be especially rigorous in this way because they were still breaking free of the demons of Valentine v. Chrestensen. By now, however, it seems appropriate to try to apply a disciplined approach instead of the more ad-hoc balancing methods used in the early cases."232

Drafting a majority opinion that would accomplish that goal and draw majority support, however, represented a considerable challenge. At conference, seven justices had indicated they would strike down the New York ban even though they disagreed with how to reach that conclusion. ${ }^{233}$ Ultimately, eight justices would join Justice Powell's judgment declaring the ban unconstitutional, but three of them authored concurring opinions to articulate their differences in conceptualizing the basis for that judgment. ${ }^{234}$ Despite all that, Powell successfully established his Central Hudson test through his opinion-crafting efforts detailed in this section. It remains to this day the most pivotal of all modern commercial speech rulings. "Justice Powell was always concerned about what judges and lawyers would do with the opinion after the Court handed down its ruling, so he liked providing the clearest possible guidance for the future - without, of course, deciding future cases," recalled David O. Stewart, the clerk with whom he worked closely with the Central Hudson opinion. ${ }^{235}$

As their development of the test proceeded, Powell expressed satisfaction that it was not "too 'elaborate' or 'academic."” In his assessment, "[t]he first step (whether the speech is 'commercial') usually will be simple. The second step (whether the governmental interest is substantial) presents a familiar question that usually is a judgment call." He deemed the rest of the test more intellectually demanding but still tenable: "The next two steps are: whether the regulation is related directly to the state interest, and whether it restricts expression unrelated to the state interest. These also are 'judgment calls', and yet they are familiar ones, and the four together do contribute - I think — to an orderly, step-by-step analysis." 236

Justice Powell did not pretend, however, that such a complex challenge 
as balancing between competing and often contradictory interests would be neatly and patly resolved in every way. Even as he proceeded to apply his nascent Central Hudson test to the facts at hand in that landmark case, he acknowledged that the delicate balancing effort it set forth forced him to devote considerable deliberation to determining how to come out "on the right side of this issue." 237 In particular he focused on how to most practically apply the subjective question of the test's fourth prong - whether the regulation in question was "not more extensive than is necessary" to serve the government's interest justifying the regulation. ${ }^{238} \mathrm{He}$ went so far as to ask his clerk to formally develop alternate analyses - one coming to the conclusion that the regulation was too extensive and another "that ends up the other way," so that he could most fully reason through the matter. ${ }^{239}$ Powell's exhaustive such efforts at that stage of the deliberations clearly document his remarkably deep commitment to finding as effective and appropriate balance as possible. Despite his aversion to government restrictions on a business' advertising, he told his clerk he also greatly feared "further disorders and revolution among the Arab states by forces that are encouraged by the USSR and that are bitterly hostile to our country," that led to another crippling disruption in the nation's petroleum supply as with the 1973 embargo that precipitated the same regulation challenged in Central Hudson. ${ }^{240}$ His concern caused him to agonize over the justification for declaring "the regulation at issue invalid merely because it reaches beyond what appears to be the immediate problem, when it might be justified as a reasonable precautionary measure for the future."241

The extent to which Justice Powell, with his avowed determination to advance business interests and particularly their ability to promulgate information and ideas, wrestled with striking the most judicious balance in Central Hudson is revelatory. It further supports an understanding of the formative commercial speech cases as forging a difficult but necessary commitment to maintain a balance between competing interests - a balance so fine that it successfully resists structural bias in either direction. Ultimately, in the Central Hudson case, it would be part four of the Central Hudson test that Powell resolved to be decisive in reaching his holding. He concluded that the regulation survived the first three prongs of the test, ${ }^{242}$ but "reaches all promotional advertising, regardless of the impact ... on overall energy use ... [and] the energy conservation rationale, as important as it is, cannot justify suppressing information about electric devices or services" that might be more energy efficient and thus could reduce total energy consumption. Finding "no showing has been made that a more limited restriction on the content of promotional advertising would not serve adequately the State's interests," his opinion declared the ban unconstitutional because it had failed to meet the standard required under the fourth prong of his Central Hudson test. ${ }^{243}$ Powell proceeded, however, to suggest that the state might "further its policy of conservation" by developing regulations that would "restrict the format and content" of such advertising, for example so as to "require that the advertisements include information about the relative efficiency and expense of the offered service, both under current conditions 
and for the foreseeable future." ${ }^{244}$ Thus, even in striking down a regulation on commercial speech, he seemed to strive toward sustaining the truest balance possible by recommending new regulation more likely to be upheld under his four-part test.

Central Hudson represented the watershed moment for the Powell Era Court's commercial speech jurisprudence. It did not resolve all debate at the Court, but it firmly fixed the cornerstone for the remaining cases during Justice Powell's tenure. In 1981, a six-vote majority for the judgment struck down a city ban on most outdoor signs in Metromedia, Inc. v. City of San Diego, though only a plurality joined Justice White's opinion announcing that judgment. ${ }^{245}$ Powell would join the plurality opinion which found that the regulation survived the Central Hudson test but still was unconstitutional because it permitted signs advertising goods or services available on sites where signs were located but did not permit noncommercial messages on those signs. ${ }^{246}$ The failure to include an exception for noncommercial speech on such onsite signs meant the regulation was unconstitutional on its face, the Court said, because "[i]nsofar as the city tolerates billboards at all, it cannot choose to limit their content to commercial messages; the city may not conclude that the communication of commercial information concerning goods and services connected with a particular site is of greater value than the communication of noncommercial messages."247 Justice White's opinion concluded that the Court was forced to apply Central Hudson in that manner because the San Diego regulation, by "affording a greater degree of protection to commercial than to noncommercial speech," had "invert[ed]" the doctrine of "recent commercial speech cases [that] have consistently accorded noncommercial speech a greater degree of protection than commercial speech." 248

Justice Powell joined an even stronger affirmation of that distinction in 1983's Bolger v. Youngs Drug Products that supplemented the first step (whether the speech is commercial) of the Central Hudson test with a threepart test for distinguishing between commercial and noncommercial speech when both elements might be present. In order to determine whether the flyers and pamphlets promoting a condom manufacturer's products - but also discussing venereal disease and family planning - could be considered commercial messages subject to federal regulation, the Court developed the three-part Bolger test to consider a combination of the advertising format of the messages, reference to a specific product, and the economic motivation for disseminating the messages. ${ }^{249}$ It stressed that no one of those three factors alone would necessarily prove dispositive, when considered together in the case at hand, "the informational pamphlets are properly characterized as commercial speech ... notwithstanding the fact that they contain discussions of important public issues." 250 That approach represented a further internal balancing component within the broader Hudson-centric doctrine, particularly in relation to step one of the four-part Hudson test. It also further distinguished commercial speech, with its dual informational and contractual components, from political speech — which does not include the latter. Justice White's majority opinion invoked Central Hudson in its asser- 
tion that "[w]e have made clear that advertising which 'links a product to a current public debate' is not thereby entitled to the constitutional protection afforded noncommercial speech." ${ }^{251}$ With that element of the Central Hudson test resolved, the Court then proceeded to apply the rest of it to the facts at hand. In doing so, it concluded that a federal ban on the unsolicited mailing of contraceptive advertisements was unconstitutional because it was more extensive than necessary to advance the government's asserted interests in protecting from such mailings those adults who might be offended and children. ${ }^{252}$

Justice Powell also joined the majority opinion in Posadas de Puerto Rico Associates v. Tourism Co. of Puerto Rico ${ }^{253}$ that upheld a ban on advertising in Puerto Rico that promoted that country's casinos. The majority applied the Central Hudson test and found the ban to be constitutional in that its restriction on a form of commercial speech advanced a substantial government interest (promoting the public welfare by reducing demand for gambling) in a manner that was no more extensive than necessary. ${ }^{254}$ Writing in dissent, however, Justice Brennan argued that Posadas had gone too far beyond the Court's prior commercial speech cases that had accepted regulation of "dissemination of information that is false, deceptive, or misleading ... or that proposes an illegal transaction," but not restrictions "designed to deprive consumers of accurate information about products and services legally offered for sale."255

Justice Rehnquist's majority opinion asserted that even though casino gambling was legal in Puerto Rico, "the Puerto Rico Legislature surely could have prohibited casino gambling by the residents of Puerto Rico altogether. In our view, the greater power to completely ban casino gambling necessarily includes the lesser power to ban advertising of casino gambling." 256 Justice Powell's notes indicate that he believed the Court reached the correct decision in applying the Central Hudson test. ${ }^{257}$ If that interpretation had gone on to be maintained as dominant with the Court in cases handed down since then, it quite arguably could have represented a potential imbalancing tilt away from substantial protection of the informational component of commercial expression. However, the fact that the Court has moved away from that interpretation - while still maintaining its doctrinal focus within the centricity of Hudson - demonstrates the strength of Hudson's structural balancing mechanism.

In cases since the Powell Era, however, the Court's commercial speech doctrine has focused most sharply on preventing government from denying citizens truthful information in advertising, particularly with regulation that seeks to discourage activities that are otherwise legal. ${ }^{258}$ In the Court's splintered 44 Liquormart $v$. Rhode Island ${ }^{259}$ decision seven years after Posadas, Justice Stevens - who had joined Justice Brennan's dissent in that case - returned to similar arguments in a part of his 44 Liquormart opinion that was joined by three other justices. "Posadas erroneously performed the First Amendment analysis," he wrote, contending that the regulation in question was actually more extensive than necessary. ${ }^{260}$ "The casino advertising ban was designed to keep truthful, nonmisleading speech from mem- 
bers of the public for fear that they would be more likely to gamble if they received it. As a result, the advertising ban served to shield the State's antigambling policy from the public scrutiny that more direct, nonspeech regulation would draw," he declared. ${ }^{261}$

Justice Stevens also rejected arguments for a "vice" exception that provided greater deference to legislative efforts that targeted activities so categorized. He declared that the scope of such an exception "would be difficult, if not impossible, to define. Almost any product that poses some threat to public health or public morals might reasonably be characterized by a state legislature as relating to 'vice activity.' Such characterization, however, is anomalous when applied to products such as alcoholic beverages, lottery tickets, or playing cards, that may be lawfully purchased on the open market." 262 Recognizing such an exception, he contended, "would also have the unfortunate consequence of either allowing state legislatures to justify censorship by the simple expedient of placing the 'vice' label on selected lawful activities, or requiring the federal courts to establish a federal common law of vice." 263

Although Justice O'Connor and the three justices who joined her concurrence in 44 Liquormart did not join that part of Justice Stevens' principal opinion, she characterized Posadas as insufficiently faithful to Central Hudson. "Since Posadas, however, this Court has examined more searchingly the State's professed goal, and the speech restriction put into place to further it, before accepting a State's claim that the speech restriction satisfies First Amendment scrutiny," she wrote. ${ }^{264}$ "The closer look that we have required since Posadas comports better with the purpose of the analysis set out in Central Hudson, by requiring the State to show that the speech restriction directly advances its interest and is narrowly tailored."265 Though that has represented a departure from the Posadas rationale that advertising could be regulated concerning activities that government could ban (whether it actually had or not), it remained consistent with the broader Powell Era emphasis on protecting the dissemination of truthful information in advertising. That emphasis was reiterated time and again in the cases of that defining period, particularly Virginia Pharmacy, ${ }^{266}$ Linmark Associates, ${ }^{267}$ Bates, ${ }^{268}$ Ohralik, ${ }^{269}$ and Central Hudson. ${ }^{270}$

In the end, the successful influence of the most experientally businessoriented justice to serve on the Court in recent decades can be seen to endure in rulings that without close consideration may seem contradictory. But in light of the historical record examined here, we can see that the corporate attorney who called for greater business influence in his 1971 "Attack" memorandum did so to address what he saw then as a state of imbalance in American society. It would become clear over the course of Justice Powell's work on the commercial speech doctrine that it was indeed balance that he was seeking, rather than giving excessive advantage to business interests over all other societal concerns. That successful institutionalization of Powellian balance is reflected in the doctrine's ongoing commitment to fairly considering competing interests that resist the tilt in either direction. It provides a structural mechanism that serves to preserve an 
adjudicational focal point that has been maintained, over time, always somewhere between unchecked freedom of the informational component of advertising and suppressive enforcement of the fair-bargaining process that is implicated in the contractual component of such speech. Justice Powell's determined assertion of his own unwavering commitment toward maintaining that fundamental balance was driven by his own deep background in historically grounded principles of sound business law, experience, and practice that shaped his constitutional considerations of First Amendment questions concerning commercial speech.

\section{Philosophical and Experiental Cornerstones}

Insight into the intellectual pillars guiding Justice Powell's understanding of those historically grounded principles can be found in his active and ongoing efforts over many years to maintain balance in informational and contractual elements involved in attorney advertising. As discussed above, his efforts were considerable, beginning in Virginia Pharmacy and continuing in later cases to focus on the concerns reflected in regulation of such advertising so as to shape the ruling along lines he felt most appropriate for the form of expression involved. His papers indicate he wrestled longest with that element of Virginia Pharmacy, pressing his fellow justices insistently to articulate the Court's greater constitutional protection for commercial speech in terms that would not undermine "the state interest in protecting professional standards" by allowing unlimited "advertising by lawyers, doctors, and other professionals." 271

Such concerns reflect consistency with his efforts at "weeding out unethical lawyers" as president of the American Bar Association in 1964 and $1965 .{ }^{272}$ The first initiative he launched was comprehensive reform of legal ethics, with a focus on canons capable of effective enforcement and disciplinary action. The project he began in 1964 was completed with the adoption of the Code of Professional Responsibility in $1969,{ }^{273}$ replacing the ABA's 1908 Canons of Professional Ethics and maintaining its ban on advertising by lawyers. ${ }^{274}$ It provided the basis for regulations on lawyer advertising that began to be challenged in a number of states in the $1970 \mathrm{~s}^{275}$ That project and the Supreme Court's evolving jurisprudence toward greater protection of truthful commercial speech would lead the ABA to work toward a less restrictive code during the same period. ${ }^{276}$ As the only member of the Court during that period who had been appointed directly from private practice, Justice Powell seemed determined to maintain the vigilance against unethical lawyers that had been a major tenet of his ABA presidency.

Further insight into such an understanding of historically grounded principles of sound business law, experience, and practice is reflected in Justice Powell's concerns with maintaining balance in business law more broadly. In Mitchell v. W.T. Grant Co., ${ }^{277}$ for example, a case that involved the extent of due-process protections related to property sequestered in a business transaction, he wrote that the "determination of what due process requires in a given context depends on a consideration of both the nature of 
the governmental function involved and the private interests affected." He characterized the governmental function involved as providing "a reasonable and fair framework of rules which facilitate commercial transactions on a credit basis, which "protect the legitimate interests of both creditor and debtor." ${ }^{279}$ Justice Powell declared that in upholding the Louisiana statute in question that the Court had wisely embraced "a fairer balancing of the interests of the respective parties" than it had in an earlier related ruling. ${ }^{280}$

That effort to maintain equilibrium among competing interests was deeply fundamental to his jurisprudence and can be seen as a consistent quality in the guiding philosophy that shaped his work at the Court. "In most cases, Justice Powell wanted to balance. That's who he was," says Stewart, the former clerk who worked closely with Justice Powell on Central Hudson. "He also wanted to give guidance to lower courts going forward, which is why he fostered so many two-part, three-prong, and fourstep tests. We, his clerks, figured this all out within a few months."281

In the commercial speech cases and others, Justice Powell's determined striving for balance between the competing interests of buyer and seller in a fair-bargaining process can be seen as more broadly consistent with a similar emphasis on balancing core elements in the Uniform Commercial Code (UCC), the most widely embraced set of guidelines for harmonizing the law governing commercial transactions. It has been adopted by all fifty states and has served as the model for other nations and for international codes, and its principles reflect an unwavering emphasis on maintaining fundamental balance between freedom of contract and the fair-bargaining process. In considering the core principles of sound business law, experience, and practice, the UCC evinces the clear institutionalization of such principles in the philosophical underpinnings for the actual body of civil law guided by the Code. Indeed, the UCC itself actually represents guidance rather law. It provides a uniform set of comprehensive guidelines that are adopted by legislatures on a state-by-state basis, but individual states may make nonuniform amendments and state courts may develop nonuniform interpretations of particular provisions. ${ }^{282}$

The resolute, overriding balance between freedom of contract and the fair-bargaining process that is maintained in all UCC guidelines and is intrinsic to any understanding of them provides contextual support for this monograph's articulation of Justice Powell's efforts to structure core principles of sound business law, experience, and practice as centric to modern commercial speech jurisprudence. The Code fundamentally establishes "a broad policy favoring freedom of contract in commercial dealings and flexibility through agreement." ${ }^{283}$ And at the same time, the most significant limitation on that broad freedom of contract is that "the parties may not disclaim the obligations of good faith, diligence, reasonableness, and care imposed by the Code." ${ }^{284}$ Thus, the firm maintenance of that overriding balance between dynamics-in-conflict in all considerations of the UCC is proposed here as support for understanding the Supreme Court's modern, Hudson-centric commercial speech doctrine as philosophically consistent 
with historically grounded principles of sound business law, experience, and practice.

While the UCC is a massive document, filled with lawyerly language and exceptions to exceptions to exceptions, its commitment to maintaining that often quite problematic balance is striking. Throughout all the myriad provisions of the UCC, it is the maintenance of that balance that is the unifying theme - an unwavering assertion that freedom and fair bargaining must both be maintained in order for commercial transactions to be truly lawful. That theme can be understood as similarly representing the "unique aspect of commercial speech," as Farber articulated it, as "a prelude to, and therefore ... integrated into, a contract, the essence of which is the presence of a promise." 285 In that sense, to consider First Amendment protection for commercial speech only in a theoretical marketplace-of-ideas vacuum discrete from the realities of the commercial marketplace - perpetuates what Dibadj called the "penultimate anomaly, ... an unwillingness to ask why a government that can regulate an underlying commercial transaction should not be able to regulate speech promoting the same commercial transaction." 286

The UCC is too practical a work to maintain such an abstract dissociation between its own fundamental dynamics, essential as they are to maintaining a successful commercial marketplace. For it exists not as an arbitrary imposition of government but as a comprehensive set of guidelines engendered through the business community's historical experience with the sort of practices most conducive to development of commerce. It serves "to simplify, clarify, and modernize the law of commercial transactions, and to permit the continued expansion of commercial practices by custom, usage, and agreement of the parties." 287 As discussed in the previous section, the jurisprudence of the Supreme Court justices who constructed the formative body of rulings on First Amendment protection for commercial speech suggests a similarly practical conceptualization of the critical elements involved.

The Uniform Commercial Code's bedrock grounding in the corollary principles of freedom and fair bargaining is stated in terms that make quite clear their inseverability: "The effect of the provisions of this Act may be varied by agreement, ... except that the obligations of good faith, diligence, reasonableness, and care prescribed by the Act may not be disclaimed by agreement." 288 As one authoritative treatise on the UCC puts it, "[t]he general rule is that parties are free to make their own contracts for the sale and purchase of goods.... [F]reedom of contract is the rule rather than the exception." 289 The prominence of that rule's bias in favor of freedom is matched by that of the Code's fair-bargaining rule: "Every contract or duty within [the Uniform Commercial Code] imposes an obligation of good faith in its performance and enforcement." 290

It "sets forth a basic principle running throughout the Uniform Commercial Code. The principle is that in commercial transactions good faith is required in the performance and enforcement of all agreements or duties," another treatise states. Even though "this duty is explicitly stated in 
some provisions of the Uniform Commercial Code, the applicability of the duty is broader than merely these situations and applies generally ... to the performance or enforcement of every contract or duty within this Act." ${ }^{291}$ It calls for "first, honesty in fact and second, the observance of reasonable commercial standards of fair dealing.... This requirement is unwaivable. Parties cannot contract away good faith." 292 Additionally, the UCC "divides the world into two classes of people - 'merchants' and 'nonmerchants,' ... [with] 'merchants' held to higher and stricter standards" than nonmerchants — buyers who are not merchants but rather ordinary consumers. ${ }^{293}$

Indisputably, maintaining both principles of freedom and fair bargaining as such constant and paramount priorities is often far from an easy matter. In "an ancient and continuing dispute," for example, the Code has often "steered a crooked course" back and forth between whether objective or subjective forms of tests are most effective in determining good faith in complex cases. ${ }^{294}$ Recent decades have favored objective measures focused on the current standard of "honesty in fact and the observance of reasonable commercial standards of fair dealing." ${ }^{295}$ But crucially, the fact that maintaining such a balance is difficult has not led to evolving the UCC so as to diminish the prominence of either element in its broad application. Quite similarly, the Supreme Court's Hudson-centric commercial speech doctrine acknowledges the difficulty in maintaining a doctrinal balance between protecting the freedom of the informational component of advertising while preserving the fair-bargaining process implicated in the contractual component of such speech.

While the Central Hudson test may not have "served that goal perfectly," 296 it has performed well enough that over the more than three decades since it was introduced, no majority of the Court has found a better way. The UCC reflects a deep and consistent commitment to preserving the fair-bargaining process, reflecting the reality that "[m]isrepresentation, duress, overreaching, and unconscionability are well-known contract doctrines," so in Farber's assessment: "When the state attacks these problems with modern regulatory tools, it can legitimately claim an interest quite distinct from the suppression of free expression." ${ }^{297}$ That is, since commercial transactions are so justifiably subject to extensive regulation - as attested to in the exhaustive provisions of the UCC - it is similarly justifiable to "include the attachment of liability to the use of language in connection with" such transactions. ${ }^{298}$

In taking further the analogical case for providing commercial speech an intermediate level of First Amendment protection - rather than the higher level accorded political expression - Posner has utilized economic analysis to demonstrate the sharp distinction between the two forms of speech. For a "scientific, ethical political, aesthetic, or religious idea," the "potential audience through the ages may greatly exceed the audience of the original expositor of the idea; the difference is a measure of the idea's external benefits." 299 That is, "the truth of many ideas and the beauty of most art cannot be resolved by any forensic practices, but must be left to the verdict of time. Neither Copernicus' theory of the solar system nor Einstein's theo- 
ries of relativity could be verified at the time they were announced (let alone by a court!). Nor could Shakespeare have been pronounced a great writer at the time his plays were written." 300

In contrast, Posner proposes, "Most of the benefits of advertising a particular brand of good or service ... are captured by the producer of that brand." 301 And whereas the "law's evidentiary methods ... seem pretty hopeless for resolving difficult questions of political or scientific truth and consequence, or aesthetic value and consequence, either on the cost or benefit side," 302 a "false representation regarding the price, quality, or quantity of a good or service offered for sale can usually be unmasked in a legal proceeding without a great expenditure of time and money or a great risk of error." 303 Therefore, since the capture of external benefits is relatively so much more immediate with commercial speech, in that analysis "[p]olitical speech simply is more vulnerable to suppression by government regulation" and justifies more absolute protection. ${ }^{304}$

Indeed, the business community has readily and widely embraced the elaborate protocol represented by the Uniform Commercial Code and its fundamental balance between protecting both the fair-bargaining process and freedom of contract. And yet in political discourse, a different trend developed in the later part of the twentieth century that was broader than the parameters of the commercial speech doctrine and would serve to tilt societal standards in countless ways out of any such balance. Just as the long view of human experience in this context provides considerable support for historically grounded principles of sound business law and practice over ideology, once again this most recent chapter offers lessons in the hazards of ideologically driven imbalance in economic affairs. As noted in the introduction, the current vantage point offers opportunities to assess evidence that we have lived through an end of an era of ideologically driven imbalance of economic affairs that represents a test case that can affirm the enduring value of the Powellian balance. The dramatic events of that episode, in such a recent evolution in political and economic culture, present an uncommonly instructive opportunity in this monograph to take theoretical analysis beyond abstract discussion and place it in historical context that demonstrates support for its applicability in the course of actual human affairs.

\section{An Era of Ideologically Driven Imbalance}

Over the decades since Central Hudson, considerable discourse has challenged more broadly the need for the sort of balance in business law that would justify — among many other things — a commercial speech doctrine that maintained justification for preserving the fair-bargaining process implicated in the contractual component of advertising. Such discourse quite often stands in contrast to the historically grounded principles of sound business law, experience, and practice reflected in Justice Powell's Hudson-centric doctrine maintaining balance in commercial speech constitutional jurisprudence. Rather than balance, that discourse has promoted an ideological understanding that serves to promote relegating protection of 
the fair-bargaining process to a subordinate status regarding freedom of contract.

The potential hazards of such imbalance in the economic marketplace and marketplace of ideas played out quite dramatically and publicly in the economic crisis of 2008. The greatest testament of the staggering devastation such imbalance can wreak would come not from those who opposed what Posner described as the dominant "doctrinaire, free-market, pro-business, anti-regulatory ideology," 305 but from a great many of those who had up until the brink of the economic crisis been its most avid proponents. The role that fraudulent representations played in the global economic crash that unfolded during the latter months of 2008 have since been reported upon and analyzed at considerable length. The role that historical developments over the three decades preceding that crash played in unleashing such representations has also been well documented.

Discourses that would prove dominant in political culture during that time were signaled with some of the most prominent pronouncements by American presidents over the course of the era. "Government is not the solution," Ronald Reagan told the world minutes after being sworn into office in January of 1981. "Government is the problem."306 His inaugural address marked the most prominent institutionalization of rhetorical strategies that had been advanced broadly and successfully during the previous decade. They powerfully reshaped the assumptions and behavior of business leaders, politicians, government officials, economists, and countless other individuals. It is through "a belief system - a set of theories, beliefs and myths with some internal coherence ... [that] seeks to universalize the interests of one social sector to the whole community," as sociologist Walden Bello has articulated the complex social process, that "an ideology is internalized by large numbers of people."307

Central to the movement was promotion of an understanding that "freeing market forces from state restraints ... [will] work to the good not only of business, but also to that of the whole community." ${ }^{08}$ It proved such an effective organizing principle that in a relatively short time it "became canonical, solidified into a new orthodoxy that anathematized all alternative ways of understanding democracy, history, and the rest of the world."309 It proved so powerful that in 1996, a president whose election largely was opposed by Reagan's constituencies nevertheless similarly proclaimed: "The era of big government is over." 310 Indeed, Bill Clinton advanced that understanding so extensively that Posner has pronounced him "the consolidator of the Reagan revolution."311

Pronouncements from presidents whose careers were so disparately grounded politically provide indications of just how successfully the ideological narrative unifying them was constructed and advanced over the course of the latter decades of the twentieth century. The roots of the rhetorical strategies that drove the narrative began to come into focus as a forceful reaction to successful public-interest activism of the $1960 \mathrm{~s}^{312}$ Regulatory initiatives - advancing cleaner air, safer automobiles, better food labeling, lending reform, and a broad range of other consumer protections - had not 
"intruded so emphatically on the business community's patterns of operation" since the "trust-busting days of Theodore Roosevelt." 313 Concluding that, as an executive of the National Association of Manufacturers put it, "[l]egislators have tended to be more receptive to the public interest than they might have been to business," the business community began striving more aggressively for greater collective influence on the legislative process. ${ }^{314}$ If indeed, the regulatory activity had tilted excessively in favor of protection of the fair-bargaining process and out of balance to freedom of contract in the sixties, the tilt back would soon come with explosive force. The numbers of Washington offices of Fortune 500 companies and corporate political-action committees skyrocketed. ${ }^{315}$ By the end of seventies, there were more individuals representing the interests of private industry working in Washington than there were federal employees. ${ }^{316}$

The unprecedented mobilization of business interests focused not only on "virtual dominance of the legislative process in Congress" 317 but also on extensive rhetorical strategies asserting that business influence represented the public interest more effectively. The period saw the rise of a body of literature known as "management theory," a genre in which an "army of management theorists" holds forth "the corporation as the ideal vehicle for economic democracy." 318 In 1972, more than 200 of the chief executive officers from the nation's largest corporations joined together to create the Business Roundtable and express a unified political voice through lobbying of legislators, campaign-finance spending through political-action committees, and media activities designed to shape public opinion. ${ }^{320}$ John D. Harper, a chairman of the Roundtable in the early seventies, said the organization "launched a new-style political activism on several fronts" designed to curb the influence of the public-interest movement and organized labor. ${ }^{321}$ "Less than a decade later, all their objectives had been accomplished," business historian Scott Bowman concluded. ${ }^{322}$

It soon became commonplace to employ the rhetorical strategies that took root during that time, strategies that quite consistently represented protection of the fair-bargaining process as subordinate to freedom of contract. When the president of Pizza Hut was asked early in the twenty-first century in a business-section interview about a bill introduced in the U.S. Congress that would require fast-food restaurants to print nutritional information on their menus, for example, his answer was formulated in such terms: "This is an interesting debate, especially in a country like the United States, that prides itself on individual freedom. What role does the government play in mandating what people eat?" In that manner, similar questions about proposed regulations on business activity were instantly reframed as a threat of government taking away the freedoms of individual Americans. ${ }^{323}$ The regulation in question in that example of course had nothing to do with "mandating what people eat." Indeed, providing greater information for consumers would seem logically to suggest more freedom of choice, not less. But such rhetorical strategies, ideologically equating regulation of business with loss of citizens' freedom, would take such deep root in the latter twentieth century as to become fixtures in political discourse. 
Rhetoric melding of the advancement of commercial interests with mobilization efforts against endangered individual freedoms of course goes back farther than the 1970s, as in Edward Bernays' 1929 "torches of freedom" that linked the women's rights movement with the American Tobacco Company's marketing efforts, ${ }^{324}$ or the "American Way" images from the Depression-era campaign of the National Association of Manufacturers. ${ }^{325}$ Yet it was in the 1970s that the phenomenon could be seen to have gathered force in more significant terms of broader ideological impact. Aggressively advanced in media and legal discourses and aided favorably by events and trends of that era, the interests of big business were more successfully than ever before synthesized with core freedom values. The narrative power of that effort to imbue the times with a sense of meaning and direction built such momentum that as the seventies ended and the eighties began to unfold, it had firmly taken root.

One of the most useful set of texts documenting discursive components critical to the construction of the broader ideology can be found in the massive body of essays disseminated by the Mobil Oil corporation, most prominently on the op-ed pages of The New York Times over the course of the 1970s. Those paid advocacy messages of Mobil's, packaged on the editorial pages of the newspaper similarly to the other opinions and commentaries published there, represented an abundant body of business rhetoric focused almost exclusively on efforts to influence political and social outcomes. Although other corporations produced advocacy messages, Mobil spoke far more regularly on other issues of public policy, inspiring a sharp rise in the numbers and extensiveness of corporate advocacy campaigns. ${ }^{326}$

Mobil waged that influential campaign with an ideological force and consistency that broadly represented freedom of contract as essentially synonymous with democracy. Variations on that theme had appeared before in business discourse, seeking to address the widely held distrust of concentrated economic power that had been a part of the American psyche since its founding. But no effort so compelling and comprehensive as Mobil's had ever been sustained. Mobil published op-ed messages in the Times on at least 445 occasions between 1970 and 1980. Although more than half of the company's opinionated messages of that period dealt with issues related to petroleum and various energy matters, a great many others addressed separate subjects. Mobil was called "the champ of advocacy advertising" by Fortune magazine and "the leading practitioner of 'issue' or 'advocacy' advertising" throughout the 1970s by Ad Forum. A 1978 Yankelovich, Skelley, and White survey found that ninety percent of administration, congressional, and other government officials read the Mobil op-ed ads. ${ }^{327}$ As a public relations vehicle, Robert Heath's 1997 assessment of Mobil as "the most visible - and feistiest - corporate practitioner of advocacy communication" for the past quarter century is typical of its characterization in corporate-advocacy literature. ${ }^{328}$

Beyond that realm, however, Mobil's messages provided a prescient vision of what lay ahead in American political culture, championing the rise of a broader ideological narrative. In Mobil's massive campaign, the cor- 
porate citizen was consistently and creatively represented as no different from any other decent, hardworking, ordinary citizen, trying to go about its business, but hounded incessantly by the destructive forces of government. Thus, in that conceptualization, when human citizens reject government regulation of corporate activity they are protecting themselves from government persecution. Increasingly equating the interests of big business with the interests of the people in its op-ed messages, Mobil pushed for citizens to pressure legislators to free Americans from government interference with business. When government threatened the rights of the corporation which was how Mobil invariably characterized regulatory efforts - it was threatening the rights of individuals. "If some politicians won't listen to reason, perhaps they'll listen to the people," Mobil warned in one of its Times spots, in language typical of its calls for action on its various causes. "What's needed now is a public outcry. Isn't it time you spoke up? Your future may depend on it." 329

In the 1970s Mobil was far from just another citizen but rather one of the half-dozen largest oil companies in the world formed out of the divestiture of parts of John D. Rockefeller's gargantuan Standard Oil Trust after its ordered breakup as an illegal monopoly was upheld by the Supreme Court in $1911 .{ }^{330}$ Its campaign played out at a time in American history when energy crises, declining productivity, and rising inflation were slowing the U.S. economy. ${ }^{331}$ Political debate centered on what should be done to resolve the tangle of dilemmas that dragged on through virtually the entire decade. Mobil aggressively and unapologetically weighed in on the debate. "When we began, advocacy, or 'public issue' advertising was ... of rather dubious legitimacy in some eyes," Mobil noted. "That corporations had ideas as well as products seemed to trouble a fair number of people." 332 Crucial to the brashness of the company's approach was Herbert Schmertz, a combative, articulate practitioner of public relations, who was named vice president for public affairs at Mobil in 1969 and was elected to the board of directors in 1976. Schmertz maintained there was no "fundamental difference between individuals and institutions" and advanced that belief as the architect of the company's advocacy campaign of the era. ${ }^{333}$

Mobil regularly replied to criticisms of its motives for seeking to influence public policy with depictions of what it declared to be the company's commitment to fostering democratic debate. The company contended that it sought only "the right of the American people, all the people, to debate freely and openly any issue that could have a pronounced effect upon their lives." It stated that legislators, government officials, and the press would not supply vital information that corporate contributors like Mobil could provide. ${ }^{334}$ "Mobil provokes, needles, challenges ... to stir free-wheeling dialogue in the public prints. Saying what we think needs saying on issues that matter to people. Inflation. Jobs. Energy. Environment," it declared. "Voices of business balance other voices. Stifling any voice distorts the democratic process." 335 That vision of the role of business in American democracy would be synergized crucially with social and political forces gathering momentum over the same period. When the 1970s had first begun 
to unfold, it had appeared American society might be ready to back another significant wave of legislative reform of business, advancing greater government enforcement of the fair-bargaining process, as in the Progressive, New Deal, and the 1960s. Instead, electoral majorities went on to repeatedly embrace candidates who espoused the central rhetoric of the pro-business, anti-government, anti-regulatory ideology promoted by Mobil and other business interests, powerfully tilting instead toward an imbalance that more greatly favored freedom of contract.

A month before the November 1980 election, Mobil launched a series of Times op-ed spots that in thinly veiled language called for voters to change leadership in Washington and free big business, promising that the energy crisis would be ended if Americans made the right choice: "The choice between a safe degree of energy security and continued or increased dependence on foreign oil depends on choices made by the American public." 336 Mobil insisted, "Everything needed to meet increasing proportions of higher energy demand with domestic supplies is available to us - everything except appropriate government policy." 337 On the Thursday before the Tuesday election, Mobil declared: "Our country has reached a point at which fundamental energy decisions must be made - decisions that can alter the course of history.... We believe the American people will respond positively to this historic opportunity." 338 That election brought the triumph of Ronald Reagan who more compellingly than any other would in plain language synthesize the freeing of business interests from government regulation with the protection of regular Americans' liberty. As in Mobil Oil's campaign, he promised that the woes that plagued the nation in the 1970s could only be righted by making business more dominant in the political equation.

The essence of Reagan's core message was never distilled more purely than the day he was first sworn in as president. Throughout that speech, the rhetoric was phrased in terms of the way government robbed regular Americans of their freedoms. "Our concern must be for a special interest group that has been too long neglected... They are, in short, 'We the people,' this breed called Americans," Reagan said. ${ }^{339}$ "It is time to check and reverse the growth of government, which shows signs of having grown beyond the consent of the governed.... It is no coincidence that our present troubles parallel and are proportionate to the intervention and intrusion in our lives that result from unnecessary and excessive growth of government." 340

Over decades of making public speeches, first as a popular corporate spokesperson for General Electric in the years leading to his political ascendance and then in a variety of more direct political messages, Reagan had perfected populist phrasing that ideologically advanced protection of the fair-bargaining process as subordinate to freedom of contract. "It isn't unfair to say that today the world is divided between those who believe in the free marketplace and those who believe in government control and ownership of the economy," he said in comments that broadly equated all government regulation with the managed economies of socialist nations. ${ }^{341}$ Reagan's 
calls for lowering corporate taxes were a recurrent cause in his speeches, representing such taxes as impositions upon individual citizens. "Whether it be corporation or corner store, taxes are part of business costs and must be recovered in the price of the product. Meaning that all of us as consumers pay those taxes," he said. "Government can't tax things like business or corporations, it can only tax people." 342

Thus, Reagan represented government as playing no legitimate role in balancing the fair-bargaining process. "Our problem is a permanent structure of government insulated from the thinking and wishes of the people.... Only you and I can change that. We must send congress a mandate to restore government to the people." ${ }^{343}$ Government regulation in the interests of citizens was framed as an idealistic notion from the past that had outlived its need. "Most of us have grown up thinking of government regulation as designed to keep big business in its place.... That was the original idea," Reagan would tell audiences in order to set up his explanations of how misguided such notions had grown. ${ }^{344}$ Such regulation actually was costing Americans tens of billions of dollars annually in "administrative salaries and overhead" and "increased prices — inflation if you will caused by unnecessary regulations," in Reagan's refiguring of the relationship between the governed and government regulation of business. That, he insisted, called for reducing the influence of government in favor of a system in which "the laws of the marketplace can replace useless regulations and create real savings for consumers." 345

Such rhetoric closely paralleled that of corporate discourse such as Mobil's. "Government can become so pervasive that it becomes virtually impossible for the citizenry to turn it around and change its course," the company declared in one of its New York Times advocacy messages. "But it's doubtful that business could ever get so big or so unresponsive, because it is subject to reaction in the marketplace and to public opinion generally." 346 Just how receptive an audience had developed for anti-government rhetoric in many segments of American life was demonstrated by the stunning early seventies success of Alabama Governor George Wallace, far beyond the Old South. Reagan's rhetoric of marketplace freedom pushing back government interference offered a more palatable articulation of the anti-government rage that had driven Wallace's third-party presidential candidacy. It had Wallace dominating the Democratic Party primaries in 1972 when gunshot wounds suffered during a campaign appearance forced him to withdraw. Yet he had presciently "sensed that millions of Americans felt betrayed and victimized by the sinister forces of change" and would respond strongly if given language for channeling their resentment, historian Dan T. Carter wrote. ${ }^{347}$ Wallace drew roaring approval from crowds when he told them that their nation had come under the control of an elite opposed to the traditional values of patriotic, hardworking Americans, and as he "neared the limits of his political popularity, he opened the door for his successors to exploit the politics of anger." 348

The advancement of freedom of contract over all other societal concerns represented a natural extension of marketing trends of the latter twen- 
tieth century. Such discursive strategies symbolically meshed with broader popular narratives in which multinational corporations promoted themselves more vigorously than ever in human terms via consumer-friendly personas such as Ronald McDonald, Mickey Mouse, the Michelin Man, the Jolly Green Giant, and the Pillsbury Doughboy. Although the use of such genial, appealing figures was not new by that time, it grew far more ubiquitous and iconographic. The dynamics of such efforts complemented the rise of "branding" in management theory, in which promotion of image took precedence over production of goods. ${ }^{349}$ These trends coalesced with compelling historical developments in ways that contributed to the success of broader ideological agendas. Economic analyst Robert Kuttner wrote of it as a "marketization" that began its ascendance in the 1970s and through which "a new, radically classical economics gradually gained influence in the academy and in politics." 350 James Arnt Aune described that influence in terms of "economic correctness." ${ }^{351}$ Kenneth S. Friedman characterized the remarkable way the movement grew so widely entrenched as to represent "a set of beliefs, comparable to religious beliefs in earlier ages, about the nature of economics and societies." 352

That entrenchment contributed to a dramatic freeing of business activity from government restraint in the latter twentieth and early twenty-first centuries. Watershed changes in law and policy loosened decades of antitrust restrictions on corporate merger activity, unleashing a merger frenzy not seen since the late nineteenth century. Ultimately it made possible such actions as the rejoining of Exxon and Mobil, the two largest pieces of the old Standard Oil empire. The earlier public-interest legislative efforts of the 1960s that had spawned big business's collective backlash beginning in the next decade were reversed many times over. Taxes on corporations were slashed so extensively that by 2004 The Wall Street Journal declared: "It is hard to see how the corporate tax tally could get much smaller."353 Corporate taxes as a share of the national economy dropped to their lowest level since World War II, ${ }^{354}$ at the same time that Standard \& Poor's reported the cash reserves of the nation's five hundred largest companies alone topped $\$ 643$ billion, a figure an S\&P analyst called "out of whack with all historical numbers." 355

Ideology rejecting any regulatory role in the fair-bargaining process came to form the basis for policy making, as demonstrated, for example, by an assertion in the early 2000s by an Environmental Protection Agency administrator: "There is no environmental progress without economic prosperity." Otherwise, he said while reducing ecological science to mere bottom-line economics, "our capacity to make environmental gains is gone." 356 It proved a powerfully imbalancing mindset through which the lobbyists for power companies, by many accounts, were bestowed with as considerable control over environmental policy. ${ }^{357}$ The use of rhetorical strategies designed to institutionalize such imbalance seemed boundless. From "tort reform" to "death tax" to "the ownership society," one campaign after another advanced a broad understanding of greater freedom of contract as far more beneficial to the interests of hard-working, ordinary citizens than 
any sort of government regulation. ${ }^{358}$

Even scientific findings were so extensively repackaged as to render them more compatible with the agendas of big business that the Union of Concerned Scientists issued a 2004 report - endorsed by more than six thousand scientists - detailing the censoring and suppression of government scientists, the stacking of advisory committees with unqualified political appointees, and the disbanding of government panels that provided undesired recommendations. ${ }^{359}$ Other accounts documented the way that organizations such as the Global Climate Coalition and the Information Council on the Environment were created by the petroleum, automotive, coal, and other industries to develop campaigns repositioning global warming as theory rather than fact. ${ }^{360}$ Compounding such developments, it grew increasingly more difficult for Americans to learn about such matters from a free press, as more and more news media were reduced to subsidiaries of business conglomerates where investigative reporting largely gave way to entertainment, gossip, and punditry. ${ }^{361}$ Thus, by the first decade of the twenty-first century, the rhetoric of "antiregulation and deregulation found full expression, fueled by an ideology that markets know best, government hampers markets, and problems will magically fix themselves."362 Countless mechanisms for maintaining the fair-bargaining process had given way to an expansionary favoring of freedom of contract in the broadest sweep of economic affairs imaginable.

\section{The Hazards of Ideology Trumping Balance}

The economic downturn of 2008 presented one stunning debacle after another that fundamentally challenged the anti-regulation ideology. Both in the immediate reporting of those dramatic events and in extensive analysis that has followed, a dominant theme is the way that the ideological momentum over preceding decades had led to the abandonment of so many historically grounded principles of business. The imbalance engendered through that abandonment fostered widespread business practices built on an assumption that preservation of the fair-bargaining process was no longer necessary. The developments of 2008 brought, as financial reporter Andrew Ross Sorkin has since described it, "a near collapse of the financial system, forcing a government rescue effort with no precedent in modern history.... Wall Street had gone from celebrating its most profitable age to finding itself on the brink of epochal devastation. Trillions of dollars in wealth had vanished." 363

As the mind-boggling collapse of markets and the global economy began to unfold, day-to-day events challenged the certainty of recently dominant ideological constructs with dizzying speed. Indeed, any number of events from the latter months of the year - in and of themselves - stand as fundamentally incompatible with such constructs. When the Administration announced in early September that the federal government was stepping in because months of efforts to find a private buyer for the nation's two largest mortgage finance companies had failed, the move was described as "an extraordinary federal intervention in private enterprise ... 
[that] could become one of the most expensive financial bailouts in American history." Indeed, Treasury Secretary Henry M. Paulson Jr., who engineered the federal takeover of mortgage giants Fannie Mae and Freddie Mac, "would not say how much capital the government might eventually have to provide." 364 The nation had less than a week to grasp the news that the business community could not save its two dominant mortgage financiers - while government ostensibly would be doing so - when it learned that two of the largest securities firms on Wall Street were also negotiating for government aid. Those talks concluded with the 158-year-old Lehman Brothers going bankrupt and Merrill Lynch agreeing to be bought out to avoid collapse, both due to massive losses from bad mortgage-finance and real estate investments. ${ }^{365}$

Peter G. Peterson, who had formerly served as head of Lehman and as secretary of commerce, called the developments "the most extraordinary events I've ever seen." "366 Yet within days, news emerged that global insurance giant American International Group (AIG) was also imploring the federal government to save it from a similar collapse. ${ }^{367}$ Desperate to avoid another major corporate collapse, the government began pouring tens of billions of dollars into AIG. ${ }^{368}$ When Paulson called Congressional leaders together to let them know that the government must assist AIG - because no private firms were willing or able to do so - he considered the move so unthinkable that he did not reveal the purpose of the meeting until after they had gathered. When he told them the real reason for the meeting, an aide to Paulson reported it left the legislators "petrified."369

Executives and analysts pronounced the developments as epochal, predicting that banks would shrink, profits would decline, and jobs would grow scarce. ${ }^{370}$ The Dow Jones Industrial Average fell to a seven-year low. ${ }^{371}$ Reports began to reveal just how disastrously the collapsed firms had been managed in the age of minimalist regulation, as the staggering depth and breadth of imprudent lending emerged. ${ }^{372}$ The American automobile industry was next to turn to the federal government to save it from ruin. ${ }^{373}$ As citizens sought to reconcile the incongruity of one business giant after another suddenly no longer condemning government intervention in their affairs but instead lining up to plead for as much of it as possible, still more ominous developments began to come into focus.

The rapid series of collapses by major firms led multitudes of investors to "frantically" pull their money from all but the safest of investments, building toward a virtual shutdown of global credit markets. ${ }^{374}$ Over a time span of a couple of weeks, government leaders found themselves quickly moving beyond the already unimaginable steps of bailing out individual corporate giants and on to a scramble to save the entire economic system from falling apart. ${ }^{375}$ That fear led to the meeting that would have been unimaginable only a short time before. On the afternoon of September 18, Paulson and Federal Reserve Chairman Ben Bernanke briefed President George W. Bush that global markets were frozen and the situation so "extraordinarily serious" that they wanted to ask Congress to authorize hundreds of billions of dollars for the federal government to buy the troubled finan- 
cial assets that were sinking so many private companies. After hearing out their proposal, Bush replied, "We need to do what it takes to solve this problem," The Wall Street Journal reported. ${ }^{376}$ By "we," he was referring to the government. Another president of similar ideological bent may have famously declared that "government is not the solution," but now his political heir was agreeing to sign off in dramatic fashion on precisely the opposite proposition. President Bush's decision set up a meeting that evening with Congressional leaders, at which Paulson told them that if they did not also authorize such a solution: "Then heaven help us all."377

Those dire days led global billionaire financier George Soros to proclaim that "both Marxism and market fundamentalism are false ideologies." 378 The Wall Street Journal characterized the developments as "The Week That Changed American Capitalism." 379 For it was not just that the rhetoric of more than a quarter-century had been abandoned by some of that rhetoric's most prominent promulgators, it was also the dizzying speed with which they were insisting the turnabout must be put into place. After decades of rejecting virtually any role for government in business matters, devout free-market ideologues were now demanding that government pump out unprecedented public financing for private endeavors - and do so immediately. President Bush and Treasury Secretary Paulson told Congress that it must approve an almost incomprehensible $\$ 700$ billion for their plan within days in order to avert economic catastrophe - even though the plan itself was not even completed. ${ }^{380}$ For the first time in his presidency, President Bush delivered a prime-time televised address devoted exclusively to the economy. He appealed for support for the plan, which by then had a name: TARP (Troubled Asset Relief Program). Warning that failure to act quickly could mean "a long and painful recession," the president declared: "Fellow citizens, we must not let this happen." 381

The sudden new role of government as solution, rather than problem that the Administration had been conceptualized in Paulson's proposal one of virtual omnipotence was the ultimate in attempted reversal of imbalance. A treasury secretary who only months before was still forcefully advocating a highly limited role for government now called for a virtually unlimited role for it. The original draft of the TARP stated: "Decisions by the Secretary pursuant to the authority of this Act are non-reviewable and committed to agency discretion, and may not be reviewed by any court of law or any administrative agency." Sorkin characterized the provision as vesting a single government official "with perhaps the most incredible powers ever bestowed on any one person over the economic and financial life of the country." 382 Congress seemed unable to accept at first that such a wrenching ideological contortion could be conceivable, and concern about the cost generated enough opposition in the House of Representatives to defeat the proposal in the first House vote on it. ${ }^{383}$ But after stock markets began plunging even as the voting was taking place on C-SPAN - the Dow Jones ultimately fell a record 777 points that day — fifty-nine members of the House switched their votes and the plan won approval. Although some changes were made through the legislative process, "lawmakers succeeded 
little in imposing control over use of the funds," the Journal reported, "the core of what Mr. Paulson requested survived largely unscathed." 384 Time would show, however, that in fact such attempts at reversing the impact of decades of imbalance overnight was not in reality possible.

The Journal called it "Black September, the biggest financial shock since the Great Depression." ${ }^{385}$ Alan Greenspan, whose deregulatory policies during his 19 years (1987-2006) as chairman of the Federal Reserve were grounded in his faith in the self-correcting power of free markets, told Congress in October of 2008 that he had been left "in a state of shocked disbelief" by recent developments. "This modern risk-management paradigm held sway for decades," he said. "The whole intellectual edifice, however, collapsed." "386 Indeed, within just a few months time, "the shape of Wall Street and the global financial system changed almost beyond recognition," Sorkin wrote. In addition to the five largest investment banks all failing, being sold, or converted into a bank holding company, "with the stroke of a president's pen, the Treasury - and by extension, American taxpayers became part-owners in what were once the nation's proudest financial institutions, a rescue that would have seemed unthinkable only months earlier." 387 As the initial shock of events has begun to recede into history, it has been followed by extensive investigative reporting and economic and historical analysis in which the most prominent theme underlying the events of 2008 is the way that a fundamental imbalance in the fair-bargaining process - ideologically spurred forward since the latter decades of the twentieth century - contributed to the collapse that resulted.

Posner's analysis of the crisis focuses on the decades-long trend toward imbalance, particularly the way the "movement to deregulate the financial industry went too far by exaggerating the resilience - the self-healing powers - of laissez-faire capitalism." ${ }^{388}$ That imbalance was driven primarily by such imprudent deregulation of the financial sector at the same time that similarly short-sighted policy kept interest rates lower than warranted in a "confluence of two dangerous developments" that led to excessive investment in relatively riskier investments by consumers, bankers, and other financiers. ${ }^{389}$ "The trends toward easy credit and deregulated and therefore risky lending were mutually reinforcing," Posner concluded, finding ideology "played a role" in the "professional blindness" of most economists" "inexcusable" failure "to have grasped the dangers that have now produced the first U.S. depression since the 1930s." ${ }^{390}$

Reporting on the economic crisis by veteran business journalists described the ways that financial trends in the years leading up to it had turned away from historically grounded principles of business toward practices that prioritized short-term gains. In a relatively short time, "Wall Street's business model had shifted from giving advice to taking on risk" and money was made not through successful long-term investment but by "weighing the odds and then making decisive, and massive, bets," wrote veteran business reporter Charlie Gasparino. ${ }^{391}$ Traditional business analysis was discarded in favor of staggeringly complex computer models that dismissed fundamentals such as "what a company actually made and 
whether it made it well." ${ }^{392}$ Lessons learned and relearned over preceding centuries concerned with greed and irrationality in market behavior were abandoned for a blind faith in an absolute predictability offered by the newfound methods of algorithmic analysis. ${ }^{393}$ Ultimately, when "possibly the biggest, fastest, and strangest financial collapse ever seen" unfolded in 2008, "not one of the quants, despite their chart-topping IQs, ... their decades studying every statistical quirk of the market under the sun, saw the train wreck coming."394

Such abandonment of principles deeply grounded in historical experience characterized the reasoning that rose to dominance at one massive financial institution after another. At lenders like Ameriquest, investment houses like Lehman Brothers, and countless related entities, lending standards and underwriting were weakened to the point of nonexistence as "the drive to increase loan volume trumped concerns about fraud," found investigative journalist Michael W. Hudson. ${ }^{395}$ "Investors and regulators alike" were sold "on the idea that it was possible, through accounting alchemy, to turn risky assets into 'Triple-A-related' securities that were nearly as safe as government bonds." 396 Wall Street traders persuaded government officials to sign off on changes in law and policy that "gave rise to a mortgage-backed securities market that was far more dysfunctional than anyone realized at the time," financial reporters Bethany McClean and Joe Nocera have documented. ${ }^{397}$ The belief that the financial verities of the ages had been somehow repealed rippled so widely through society in the years preceding the 2008 crash that, particularly via aggressive promotion of "subprime lending" to countless borrowers whose credit records traditionally had made them too risky for most lenders, home mortgages grew "preposterously easy to get, with millions of Americans moving into luxury housing they couldn't afford and millions more using the bubble-addled housing prices to turn their homes into personal ATMs" through refinancings and home-equity loans. ${ }^{398}$ Under such conditions, almost any legitimate attempt at preservation of the fair-bargaining process was abandoned. Attorney and former bank regulator William K. Black said that in some categories of the riskier loans, ninety percent were found to involve fraudulent activity. ${ }^{399}$

In large part, the collapse of Lehman Brothers, established for more than a century and a half and the fourth largest investment house in the United States, continued to place bigger bets on the sustainability of such unsustainable propositions. ${ }^{400}$ When "the great real estate bubble that helped fuel growth in the financial sector for much of the decade" burst, it also "mortally wounded" investment giant Merrill Lynch. ${ }^{401}$ A company built over many years on a business model focused on restoring the faith of small investors in the market after the Great Depression through prudent investing had rapidly shifted into high-stakes investment banking in the twenty-first century and doubled in size between 2005 and 2007. ${ }^{402}$ The collapse of the mortgage-investment market brought Merrill Lynch down just as rapidly, resulting in such massive losses that it had to agree to be acquired by a similarly weakened Bank of America in a transaction that ultimately required some $\$ 45$ billion in assistance from the federal govern- 
ment. ${ }^{403}$

The process that over time produced such disregard for historically grounded principles of sound business practice has been described as one in which "a kind of public utility" focused on providing a generally reliable flow of investment returns and lending options - much as the flow of water and power are provided by other utilities - "drifted away from its core intermediary function and morphed from utility to casino." 404 That metamorphosis of Wall Street "from a utility serving Main Street to a business that took extraordinary risks to maximize its own profits at the expense of that utility function set the stage for that crisis." 405 The transformation also tilted the contentious balance between prudence and risk significantly away from the stabilizing influence of risk managers. Though specialists of that sort on Wall Street were "about as popular and welcome as a sensible spouse or cautious bank manager whispering words of reason to a Vegas gambler about to bet the ranch at blackjack," they "knew instinctively or had learned from experience that when it seemed as if nothing could go wrong, it was time to look around for the hidden iceberg ready to rip a hole in the side of the vessel." 406 As "Wall Street's magical thinking" increasingly denied such established verities in the years leading up to 2008, those who persisted in urging measures of prudence "might be proven right in the long run, but for now would be laughed at and shunned, and perhaps even lose their jobs." 407

Such magical thinking seemed to have no bounds in that era. In writing about how the subprime lending industry actually collapsed when it was much smaller in the late 1990s, financial journalist Michael Lewis himself once a bond trader- observed that the "market might have learned a simple lesson: Don't make loans to people who can’t repay them." 408 But rather than that lesson, he found, "it learned a complicated one: You can keep on making these loans, just don't keep them on your books. Make the loans, then sell them off to the fixed income departments of bit Wall Street investment banks, which will in turn package them into bonds and sell them to investors." ${ }^{409}$ In that mentality, and the lack of regulation that would have restrained it in the name of preserving the fair-bargaining process, can be seen the way an absolute antithesis to any such preservation had taken very deep root. "By early 2005 all the big Wall Street investment banks were deep into the subprime game," Lewis wrote. ${ }^{410}$ Within a few more years, such practices had expanded imprudent lending far beyond subprime borrowers to by some estimates half of all mortgages made during that period. "Insolvent borrowers meant insolvent lenders, insolvent builders, and insolvent hedge funds," adding up to "an insolvency crisis that would affect the U.S. and the wider global economy." 411 Through that process, the undermining of the fair-bargaining process itself was in effect securitized exponentially as the considerable risks were distributed out upon the countless parties involved in the complex web of mortgage transactions, most of whom were neither provided nor had the level of financial acumen necessary to understand the level of that risk. ${ }^{412}$ Even among those who did understand it, few were able to escape the devastation. "In some 
ways, Wall Street was undone by its own smarts, as the very complexity of mortgage-backed securities meant that almost no one was able to figure out how to price them in a declining market," Sorkin has concluded. ${ }^{413}$

In the context of this monograph's greater focus, the concern here is not with assessment of the role that any particular institution or policy in and of itself played in the economic crisis. Rather it is with the disproportionate influence that ideological certainty in boundless risk played in the buildup to the economic crisis, which critically serves to illustrate how such lack of balance undermines historically grounded principles of sound business practice. The normal activities of investment houses - and other businesses to varying degrees - involve inherent risk: "If a sensible risk-balanced culture prevails, an investment bank can be a profitable money machine, but an insensible risk-balanced culture leads to disaster, as Lehman discovered." "414 Whereas, companies "that balance the tug-of-war between risk and return ... in the long run, are more profitable," risk-management analyst Mark T. Williams has detailed, when the "leveraged real estate boom screeched to a halt, and Lehman was stuck holding billions of dollars of junk loans," it suddenly became "an overloaded elephant walking on thin ice." 415 What was missing most of all was maintenance of balance between freedom of contract and protection of the fair-bargaining process. For it is precisely that balance between the two that Justice Powell's core principles and much historical wisdom holds forth as the optimal theoretical foundation for the adjudicating commercial speech doctrine, as well as for managing economic affairs more broadly. "Unchecked, Wall Street will always seek the highest profit and ignore many risks. Conversely, excessive government intervention will stifle bank profitability, vital economic growth, and prosperity," Williams wrote. ${ }^{416}$

Economic events such as those that unfolded in 2008, cataclysmic as they were for those who lived through them, are lessons that citizens have experienced throughout history. "Speculative excess ... and revulsion from such excess in the form of a crisis, crash, or panic can be shown to be if not inevitable, at least historically common," wrote economist Charles P. Kindleberger in his classic history of the phenomenon. ${ }^{417}$ As financial historian Peter L. Bernstein concluded in his history of risk, "The goal of wresting society from the mercy of the laws of chance continues to elude us." 418 Yet the theoretical justification for balance will always face the undermining of ideology and technology tempting us to believe otherwise, and it will always be under assault from the opposing camps. "The position that markets generally work but occasionally break down," as Kindleberger put it, "is widely at variance with the views at either of two extremes: that ... markets work perfectly in all times and places, or that they work badly and should be replaced by planning and governmental assignments." ${ }^{119}$

As discussed previously, the excessive ideological abandonment of regulatory balance and prudence that rose to dominance beginning in the 1970s was itself generated in response to imbalance in the other direction in the preceding era. Justice Powell in his memorandum for the U.S. Chamber of Commerce in 1971 had indeed been part of the call for such a 
response. ${ }^{420}$ And yet his time at the Court was characterized not solely by efforts to tilt the balance in favor of one interest over others but by indisputable efforts to establish an enduring mechanism of jurisprudence that would maintain balance over time. His Hudson-centric commercial speech doctrine represents his most lasting achievement of that determination to establish doctrinal balance. The Powellian balance served that purpose well over time, maintaining a difficult equilibrium over the course of a series of complex First Amendment cases between the freedom of the informational component of advertising and the fair-bargaining process implicated in the contractual component of such speech. The value of balance in general may seem self-evident, yet it clearly is not so paramount that it cannot be excessively devalued through the sort of ideological ascendance in rhetoric and practice that extensive analysis finds contributed significantly to the economic crisis of 2008. And similarly, one sees in the debate on commercial speech and First Amendment protection many competing ideological efforts to tilt it away from the sort of balance that the Hudson-centric commercial speech doctrine has institutionalized in related jurisprudence for more than three decades.

\section{Conclusion}

It is illustrative that Justice Powell - whose career background and well-documented agenda before joining the Supreme Court arguably made him the most experientally business-oriented justice there in recent decades — demonstrated such a deep commitment to balancing competing interests in the commercial speech doctrine. As a corporate attorney before joining the Court who perceived a state of imbalance in terms of business influence on American society in the early 1970s, he authored his vigorous "Attack" memorandum calling for a rectifying of that imbalance. But it would become clear over the course of his work on the commercial speech doctrine that it was, above all, balance itself that he ultimately prioritized - rather than excessively advantaging business interests over all other societal concerns. That effort markedly strove to resist tilting that body of jurisprudence toward either totally unrestrained freedom of the informational component of advertising or excessively suppressive enforcement of the fair-bargaining process implicated in the contractual component of such speech. Both Justice Powell and majorities of Supreme Court justices in the formative body of rulings on First Amendment protection for advertising repeatedly affirmed the value of finding balance - however difficult that might be from case to case.

Those who argue that the Hudson test produces conflicting results are missing the point that it is intended to produce results that may indeed seem conflicting when not examined closely. In actuality, it derives from the test's overriding objective of balance. As the Court has demonstrated in several of its more recent commercial speech cases, ${ }^{421}$ the Hudson test can be the basis for both upholding regulation on commercial speech (such as "do not call" restrictions on telemarketing ${ }^{422}$ and lottery advertising) ${ }^{423}$ and for striking down regulations on advertising (such as those involving alcohol 
content, ${ }^{424}$ prices, ${ }^{425}$ and tobacco billboards). ${ }^{426}$ Despite arguments by some justices against maintaining the centricity of Central Hudson, and even when the Court has been specifically petitioned in recent commercial speech cases to abandon that centricity, ${ }^{427}$ the majority has firmly rejected the justification for doing so: "We see "no need to break new ground. Central Hudson, as applied in our more recent commercial speech cases, provides an adequate basis for decision.", 428

In its fundamental effort to balance between complex competing interests, the facts of any particular case can justify a result that will favor - in that case, at least - either greater freedom of the informational component of advertising or advancement of contractual component preserving the fairbargaining process. But over time, neither of those components will assume a disproportionate influence in the greater body of case law on commercial speech adjudicated under the Hudson-centric doctrine. As this analysis has asserted, such a judgment is philosophically consistent with a balance in economic affairs more broadly between freedom of contract and the fair-bargaining process. These extremes are in contrast to the ideologically driven imbalance that characterized economic affairs more broadly in the decadeslong buildup to the economic crisis of 2008. The modern Supreme Court's modern, Hudson-centric commercial speech doctrine's grounding in such philosophical underpinnings provides extensive support for understanding it as consistent with historical principles of sound business law, experience, and practice.

The essential elements of the Powell Era Court's commercial speech jurisprudence have remained in place over more than three decades, despite an array of criticism in some branches of the literature and by forceful arguments against it by some justices. This monograph asserts that its hardiness in the face of such formidable challenges - and the stark and stunning contrast presented by the lessons of recent ideological imbalance's shaping influence on broader economic activity - can be attributed to its anchoring in a broader, time-tested wisdom on how to best promote vital and complex societal interests. 


\section{Endnotes}

1. Numerous articles provide fuller historical analysis of the development of the Supreme Court's commercial-speech doctrine. See, e.g., Michael Feldman, Survey of the Literature: Commercial Speech and Commercial Speakers, 2 CARDOZO L. REV. 659 (1981); Mary B. Nutt, Trends in First Amendment Protection of Commercial Speech, 41 VAND. L. REV. 173 (1988); Peter J. Tarsney, Regulation of Environmental Marketing: Reassessing the Supreme Court's Protection of Commercial Speech, 69 NOTRE DAME L. REV. 533 (1994); Sean P. Costello, Strange Brew: The State of Commercial Speech Jurisprudence Before and After 44 Liquormart, Inc. v. Rhode Island, 47 CASE W. RES. L. REV. 681 (1997); Arlen W. Langvardt, The Incremental Strengthening of First Amendment Protection for Commercial Speech: Lessons from Greater New Orleans Broadcasting, 37 AM. BUS. L.J. 587 (2000); Soontae An, From a Business Pursuit to a Means of Expression: The Supreme Court's Disputes Over Commercial Speech from 1942 to 1976, 8 COMM. L. \& POL'Y 201 (2003).

2. See infra notes 137-253 and accompanying text for fuller discussion of the cases involved in the first two phases of the Court's commercial-speech doctrine.

3. 447 U.S. 557 (1980).

4. Id. at 566 .

5. See infra notes 26, 61-74, and 259-71 and accompanying text for fuller discussion of the cases involved in the most recent phase of the Court's commercial-speech doctrine.

6. See Ronald K.L. Collins \& David M. Skover, The Psychology of First Amendment Scholarship: A Reply, 71 TEX. L. REV. 819, 699 (1993).

7. See Daniel A. Farber, Commercial Speech and First Amendment Theory, 74 NW. L. REV. 372, 386-87 (1979). In that prescient article, Farber's assessment of the fundamental difficulties involved in the Supreme Court's then just birthed modern commercial-speech doctrine can be seen as something of a blueprint for the Court's subsequent efforts to fully protect advertising that imparts truthful information while maintaining justification for regulation of contractual elements that may be false or misleading.

8. See Ronald A. Cass, Commercial Speech, Constitutionalism, Collective Choice, 56 U. CIN. L. REV. 1317, 1320 (1988).

9. See infra notes 142-253 and accompanying text on the earlier cases and contrast with that at 61-74 and 259-71 on the later cases.

10. See Cass, supra note 8 , at 1320 .

11. See infra notes 93-135 and accompanying text for fuller discussion of this aspect of Justice Powell's background and personal agenda.

12. See A.C. Pritchard, Justice Lewis F. Powell, Jr., and the Counterrevolution in the Federal Securities Laws, 52 DUKE L.J. 841, 849-54 (2003) (discussing Justice Powell's business career, in a study more broadly considering Justice Powell's jurisprudence on securities laws).

13. See JOHN C. JefFries, JR., JUStice LEWIS F. POWELL, JR.: A Biography 252-53 (2001).

14. See Thomas H. Jackson and John Calvin Jeffries, Jr., Commercial Speech: Economic Due Process and the First Amendment, 65 VA. L. REV. 1, 6 (1979) (arguing that Virginia Pharmacy was decided wrongly and that the "line of development" it began "should be cut short" because commercial expression has nothing to do with advancing the values of self-government and individual self-fulfillment protected by the First Amendment. Id. at 5-6).

15. See R. H. Coase, Advertising and Free Speech, 6 J. LEGAL STUD. 1, 31 (1977) (arguing that Virginia Pharmacy was decided rightly and that the Court should expand its holding on advertising of pharmaceutical prices more broadly, advancing his "view that the market for goods and the market for ideas should be treated in the same way." Id. at 7). 
16. See C. Edwin Baker, Paternalism, Politics, and Citizen Freedom: The Commercial Speech Quandary in Nike, 54 CASE W. RES. L. REV. 1161, 1162 (2004).

17. Id. at 1163 (citing generally Alan B. Morrison, How We Got the Commercial Speech Doctrine: An Originalist's Recollections, 54 CASE W. RES. L. REV. 1189 (2004) (discussing from the position of a cofounder (with Ralph Nader in 1972) of the Public Citizen Litigation Group and plaintiff's attorney in Virginia Pharmacy, his efforts to end "an age where consumers were kept in the dark about highly relevant information" concerning, for example, pharmaceutical prices, abortion availability, and lawyers' services. Id. at 1204).

18. Id. at 1162-63. See also C. EDWIN BAKER, HUMAN LIBERTY AND FREEDOM OF SPEECH 194-224 (1989); C. Edwin Baker, Commercial Speech: A Problem in the Theory of Freedom, 62 IowA L. REV. 1 (1976); C. Edwin Baker, Realizing Self-Realization: Corporate Political Expenditures and Redish's The Value of Free Speech, 130 U. PA. L. REV. 646 (1982); C. Edwin Baker, Turner Broadcasting: Content-Based Regulation of Persons and Presses, 1994 SUP. CT. REV. 57.

19. See Martin H. Redish, First Amendment Theory and the Demise of the Commercial Speech Distinction: The Case of the Smoking Controversy, 24 N. KY. L. REV. 553, 558 (1997).

20. Id. at 556 .

21. See Baker, supra note 17, at 1168, 1171. (distinguishing that proposition to emphasize that in order to be considered commercial, "the speech must relate to an interest in the sale of goods or services other than the speech itself. When the speech itself is the product and when the speech is made available to an undifferentiated public, the seller is the press, the one business that itself receives direct constitutional protection." Id. at 1168). See also C. EDWIN BAKER, HUMAN LIBERTY AND FREEDOM OF SPEECH 194-224 (1989); C. Edwin Baker, Commercial Speech: A Problem in the Theory of Freedom, 62 IOWA L. REV. 1 (1976); C. Edwin Baker, Realizing Self-Realization: Corporate Political Expenditures and Redish's The Value of Free Speech, 130 U. PA. L. REV. 646 (1982); C. Edwin Baker, Turner Broadcasting: ContentBased Regulation of Persons and Presses, 1994 SUP. CT. REV. 57.

22. See Martin H. Redish, Self-Realization, Democracy, and Freedom of Expression: A Reply to Professor Baker, 130 U. PA. L. REV. 678, 679 (1982) (emphasis included). See also Martin H. Redish, The First Amendment in the Marketplace: Commercial Speech and the Values of Free Expression, 39 GEO. WASH. L. REV. 429 (1971); Martin H. Redish, The Value of Free Speech, 24 U. PA. L. REV. 591 (1982); Martin H. Redish, Tobacco Advertising and the First Amendment, 81 IOWA L. REV. 589 (1996).

23. See, e.g., Lillian R. BeVier, The First Amendment and Political Speech: An Inquiry into the Substance and Limits of Principle, 30 STAN. L. REV . 299 (1978); Vincent Blasi, The Pathological Perspective and the First Amendment, 85 COLUM. L. REV. 449 (1985); Richard Moon, Lifestyle Advertising and Classical Freedom of Expression Doctrine, 36 MCGILL L.J. 76 (1991).

24. See, e.g., Alex Kozinski \& Stuart Banner, Who's Afraid of Commercial Speech?, 76 VA. L. REV. 627 (1990); Leo Bogart, Freedom to Know or Freedom to Say?, 71 Tex. L. REV. 815 (1993); Alex Kozinski \& Stuart Banner, The Anti-History and Pre-History of Commercial Speech, 71 Tex. L. REV. 747 (1993); Rodney A. Smolla, Information, Imagery, and the First Amendment: A Case for Expansive Protection of Commercial Speech, 71 Tex. L. REV. 777 (1993).

25. See, e.g., Frederick Schauer, Categories and the First Amendment: A Play in Three Acts, 34 VAND. L. REV. 265 (1981); Steven Shiffrin, The First Amendment and Economic Regulation: Away from a General Theory of the First Amendment, 78 NW. U. L. REV. 1212 (1983); Daniel Hays Lowenstein, “Too Much Puff”: Persuasion, Paternalism, and Commercial Speech, 56 U. CIN. L. REV. 1205 (1988); Edward J. Eberle, Practical Reason: The Commercial Speech Paradigm, 42 CASE W. RES. L. REV. 411 (1992).

26. See Rubin v. Coors, 514 U.S. 476, 480-91 (1995); 44 Liquormart, Inc. v. Rhode Island, 517 U.S. 484, 488-94 (1996); ; Lorillard Tobacco v. Reilly, 533 U.S. 525, 553-67 (2001).

27. See Michael W. Field, On Tap, 44 Liquormart, Inc. v. Rhode Island: Last Call For The 
Commercial Speech Doctrine, Roger Williams U. L. REV. 57, 61 (1996).

28. See Sean P. Costello, Strange Brew: The State of Commercial Speech Jurisprudence Before and After 44 Liquormart, Inc. v. Rhode Island, 747 CASE W. RES. L. REV. 681, 685 (1997).

29. See Kathleen M. Sullivan, Cheap Spirits, Cigarettes, and Free Speech: The Implications of 44 Liquormart, 1996 SUP. CT. REV. 123, 126 (1996).

30. See Timothy R. Mortimer, 44 Liquormart, Inc. v. Rhode Island: A Toast to the First Amendment, 32 NEW ENG. L. REV. 1049, 1092 (1998).

31. See Tamara R. Piety, "Merchants of Discontent": An Exploration of the Psychology of Advertising, Addiction, and the Implications for Commercial Speech, 25 SEATTLE UNIV. L. REV. 377, 432-33 (2001).

32. Id. at 450 .

33. See Ronald K.L. Collins \& David M. Skover, Commerce and Communication, 71 TEX. L. REV. 697, 710 (1993).

34. Id. at 732, 749. See also Collins \& Skover, supra note 6 (elaborating upon the subject and arguing that a more honest rationale must be developed for the First Amendment doctrine on commercial speech because it is a form of expression that aims to subvert sentiments more so than to advance ideas). See also, e.g., Sut Jhally, Commercial Culture, Collective Values, and the Future, 71 Tex. L. REV. 805, 814 (1993) (asserting that commercial speech has come to dominate culture so ubiquitously and effectively that to continue expanding its constitutional protection as a form of information represents "ideologically inspired idiocy" that imperils the "very future of the human race as we know it").

35. 539 U.S. 654 (2003).

36. Id. at 655. The Court issued a one-sentence, unsigned order dismissing its earlier writ of certiorari accepting the case as improvidently granted.

37. See Kasky v. Nike, Inc., 27 Cal. 4th 939, 969-70 (2002).

38. Id. at 656-665 (Stevens, J., concurring).

39. Id. at 665-684 (Breyer, J., dissenting).

40. Id. at 946-48.

41. See Adam Liptak, Nike Move Ends Case Over Firms' Free Speech, N.Y. TIMES, Sept. 13, 2003, at $A 8$.

42. Id.

43. Id.

44. See Deborah J. La Fetra, Kick it up a Notch: First Amendment Protection for Commercial Speech, 54 CASE W. RES. L. REV. 1205, 1207 (2004).

45. Id. at 1208 .

46. See Samuel A. Terilli, Nike v. Kasky and the Running-but-Going-Nowhere Commercial Speech Debate, 10 COMM. L. \& POL’Y 383, 386 (2005).

47. Id. at 429 .

48. See Bruce E. H. Johnson and Jeffrey L. Fisher, Why Format, Not Content, Is the Key to Identifying Commercial Speech, 54 CASE W. RES. L. REV. 1243, 1245 (2004).

49. Id. at 1244. See also Bruce E.H. Johnson, First Amendment Commercial Speech Protections: A Practitioners Guide, 41 LOY. L.A. L. REV. 297, (2007) (arguing that more narrowly allowing 
regulation only of "purely transactional speech" would assist in "leveling the playing field between those with commercial motivations and everyone else." Id. at 313-15).

50. See Tamara R. Piety, Grounding Nike: Exposing Nike's Quest for a Constitutional Right to Lie, 78 Temp. L. Rev. 151, 153 (2005). See also Tamara R. Piety, Why the ACLU was Wrong About Nike, 41 TULSA L. REV. 715 (2006).

51. See Julia Fisher, Free Speech to Have Sweatshops? How Kasky v. Nike Might Provide a Useful Tool to Improve Sweatshop Conditions, 26 B.C. THIRD WORLD L.J. 267, 269-70 (2006).

52. See Tom Bennigson, Nike Revisited: Can Commercial Corporations Engage In NonCommercial Speech?, 39 CONN. L. REV. 379, 383 (2006).

53. See Ronald K.L. Collins \& David M. Skover, The Landmark Free-Speech Case That Wasn't: The Nike v. Kasky Story, 54 CASE W. RES. L. REV. 965, 1045-47 (2004).

54. See Antony Page, Taking Stock of the First Amendment's Application to Securities Regulation, 58 S.C. L. Rev. 789, 793 (2007).

55. See Emily Erickson, Disfavored Advertising: Telemarketing, Junk Faxes and the Commercial Speech Doctrine, 11 COMM. L. \& POL'Y 589, 629 (2006).

56. See David G. Yosifon, Resisting Deep Capture: The Commercial Speech Doctrine and JunkFood Advertising to Children, 39 Loy. L.A. L. Rev. 507 (2006) (calling for a ban on such advertising as a public-policy response to its role in rising obesity rates. Id. at 510).

57. See Marla Pleyte, Online Undercover Marketing: A Reminder of the FTC's Unique Position to Combat Deceptive Practices, 6 U.C. DAvIS BUS. L.J. 55 (2006) (arguing that such techniques, through which companies pose as objective consumers in a variety of online forums, “constitute a deceptive practice." Id. at 60).

58. See Ellen P. Goodman, Peer Promotions and False Advertising Law, 8 S.C. L. Rev. 683 (2007) (asserting that the use of such online promotions in a manner that disguises the brand owner's involvement depart from a "straightforward" model based on "truthful informational advertising" in ways that reduce "the informational content of advertising." Id. at 686).

59. See Tamara R. Piety, Free Advertising: The Case for Public Relations as Commercial Speech, 10 LEWIS \& CLARK L. REV. 367, 412-13 (2006).

60. Id. at 412-13 (invoking the Supreme Court's seminal assertion in its modern doctrine on commercial speech: "The First Amendment ... does not prohibit the State from insuring that the stream of commercial information flow cleanly as well as freely." Va. State Bd. of Pharmacy v. Va. Citizens Consumer Council, Inc., 425 U.S. 748, 771-72 (1976)). See also Tamara R. Piety, Against Freedom of Commercial Expression, 29 CARDOZO L. REV. 2583, (2008) (pressing the case even further and more comprehensively in arguing the commercial-speech doctrine "ought to be interpreted more capaciously to include all forprofit motivated, promotional speech that takes place under the umbrella of marketing," with "the facts of the particular case" determining whether the speech at issue "is primarily marketing." Id. at 2675-76).

61. For fuller discussion of the Court's cases that have focused on limiting government's ability to restrict non-misleading commercial communication about lawful products and services, see, e.g., Michael Hoefges, Protecting Tobacco Advertising Under the Commercial Speech Doctrine: The Constitutional Impact of Lorillard Tobacco Co., 8 COMM. L. \& POL'Y 267 (2003); Nicholas P. Consula, The First Amendment, Gaming Advertisements, and Congressional Inconsistency: The Future of the Commercial Speech Doctrine after Greater New Orleans Broadcasting Association v. United States, 28 PEPP. L. REV. 353 (2001); Michael Hoefges \& Milagros Rivera-Sanchez, "Vice" Advertising under the Supreme Court's Commercial Speech Doctrine: The Shifting Central Hudson Analysis, 22 HASTINGS Comm. \& ENT. L.J. 345 (2000).

62. See, e.g., Waters, “A Doctrine in Disarray;” Robert Post, The Constitutional Status of 
Commercial Speech, 48 UCLA L. REV. 1 (2000); Susan Dente Ross, "Reconstructing First Amendment Doctrine: The 1990s Revolution of the Central Hudson and O'Brien Tests,” 23 Hastings Communication \& Entertainment Law Journal 723 (2001); Elizabeth Blanks Hindman, "The Chickens Have Come Home to Roost: Individualism, Collectivism and Conflict in Commercial Speech Doctrine,” 9 COMM. L. \& POL’Y 237 (2004).

63. 507 U.S. 410, 438 (1993) (Blackmun, J., concurring).

64. 507 U.S. 410 (1993).

65. 507 U.S. 410, 488-514 (1993). In cases in which no majority supports any of the opinions, only the narrowest interpretation of the judgment that did garner a majority can be considered as the holding in terms of its value as guidance for other courts. See Marks v. United States, 430 U.S. 188, 193 (1976).

66. Id. at 501 .

67. Id. at 528-34 (O’Connor, J., concurring).

68. Mainstream Marketing Services v. Federal Trade Commission, 358 F.3d 1228, 1236 (10th Cir. 2004), cert. denied, 543 U.S. 812 (2004).

69. United States v. Edge Broadcasting, 509 U.S. 418, 435 (1993).

70. Rubin v. Coors, 514 U.S. 476, 491 (1995).

71. 44 Liquormart v. Rhode Island, 507 U.S. 410, 516 (1993).

72. Lorillard Tobacco v. Reilly, 533 U.S. 525, 567 (2001).

73. Id. at 554 .

74. Id. at 554-55 (quoting Greater New Orleans Broadcasting v. United States, 527 U.S. 173, 184 (1999)).

75. See infra note 134 and accompanying text for discussion supporting the referencing of the Supreme Court that sat in consideration of cases that are the primary focus of this monograph as the "Powell Era Court."

76. See Nat Stern, In Defense of the Imprecise Definition of Commercial Speech, 58 MD. L. REV. 55,57 (1999).

77. Id.

78. See David C. Vladeck, Lessons from a Story Untold: Nike v. Kasky Reconsidered, 54 CASE W. RES. L. REV. 1049, 1086 (2004) (arguing more broadly that "although the Court will continue to tinker with the commercial speech doctrine at the margins, it is not likely to abandon the doctrine's central value of encouraging the free flow of truthful - and only truthful commercial information to consumers to enable informed decision-making.” Id. at 1087).

79. Id. at 1086 .

80. See Frederick Schauer, Commercial Speech and the Architecture of the First Amendment, 56 U. CIN. L. REV. 1189 (1988).

81. Id.

82. Id. at 1192 (asserting that if "we have to sacrifice some protection of fringe speech in order to increase the strength of the core, the price seems well worth paying." Id.).

83. See Rebecca Tushnet, It Depends on What the Meaning of "False" is: Falsity and Misleadingness in Commercial Speech Doctrine, 41 LOY. L.A. L. REV. 227, 229 (2007).

84. See Suzanna Sherry, The Rehnquist Court: Hard Cases Make Good Judges, 99 NW. U. L. REV. 


\section{3,14 (2004).}

85. Id. at 15 .

86. See JEFFRIES, supra note 13, at 252-3.

87. See Lino A. Graglia, Economic Rights, in BERNARD SCHWARTZ, ED., THE BuRGER Court: COUNTER-REVOLUTION OR CONFIRMATION? 165-66 (1998).

88. See Arthur L. Galub, The Burger Court: 1968-84 281 (1986).

89. Id.

90. Id. at 287.

91. See JEFFRIES, supra note 13, at 262.

92. See GALUB, supra note 88 , at 301 .

93. See Pritchard, supra note 12, at 947.

94. Letter from Powell, to John N. Mitchell, Attorney General, U.S. Department of Justice 1 (Dec. 12, 1969), cited in JEFFRIES, supra note 13, at 2.

95. See Pritchard, supra note 12, at 844 .

96. Id. at 946-47.

97. A.C. Pritchard, United States v. O’Hagan: Agency Law and Justice Powell's Legacy for the Law of Insider Trading, 78 B.U. L. REV. 13 (1998).

98. See, e.g., Carl J. Mayer, Personalizing the Impersonal: Corporations and the Bill of Rights, 41 HASTINGS L.J. 577 (1990).

99. See infra notes 142-253 and accompanying text for fuller discussion of Justice Powell's involvement in commercial-speech cases. Justice Powell also authored key majority opinions on corporate political media spending. See First Nat'l Bank of Boston v. Bellotti, 435 U.S. 765 (1978); Consolidated Edison v. Public Service Comm'n, 447 U.S. 530 (1980); Pacific Gas \& Electric Co. v. Public Utilities Comm'n of California, 475 U.S. 1 (1986).

100. See Fred P. Graham, Powell Proposed Business Defense, N.Y. TimEs, September 29, 1972, at A31.

101. See Memorandum from Lewis F. Powell, Jr., to Eugene B. Sydnor, Jr., Attack on American Free Enterprise System, WASHINGTON REPORT, U.S. Chamber of Commerce, August 23, 1971 at 6, on file in Lewis F. Powell, Jr. Papers, Powell Archives, Washington and Lee University School of Law [hereinafter LFP Papers].

102. Id. at 6 .

103. Id. at 1,5 .

104. Id. at 3 .

105. Id. at 7 .

106. See Kim Phillips-Fein, Invisible Hands: The Making of the Conservative Movement from the New Deal to Reagan 165 (2009).

107. See Steven M. Teles, The Rise of the Conservative Legal Movement: The Battle for CONTROL OF THE LAW 57 (2008).

108. Id. at 61 .

109. See Ann Southworth, Lawyers of the Right: Professionalizing the Conservative Coalition 
15 (2008).

110. See Ruth Bader Ginsburg, Supreme Court Pronouncements on the Conduct of Lawyers, $1 \mathrm{~J}$. INST. FOR STUDY LEGAL ETHICS 1, 9-10 (1996). See also Ginsburg, In Pursuit of the Public Good: Lawyers Who Care, 52 MAINE L. REV. 301 (2000); Ginsburg, In Pursuit of the Public Good: Access to Justice in the United States, 7 WASH. U. J. L. \& POL'Y 1 (2001).

111. See Jeffrey Rosen, The Unregulated Offensive, N.Y. TIMES MAGAZINE, April 17, 2005, at 4447.

112. 198 U.S. 45 (1905).

113. 300 U.S. 379 (1937).

114. See Ted Nace, Gangs of America: The Rise of Corporate Power and the Disabling of DEMOCRACY 137-39 (2003) (discussing the Powell memorandum in the context of the business community's reaction to legislative action that included enactment of the National Environmental Protection Act and the Clean Air Act Amendments and the creation of the Environmental Protection Agency, the Occupational Safety and Health Administration, and the Consumer Product Safety Commission).

115. See Lee Edwards, The Power of Ideas: The Heritage Foundation at 25 Years 125-26 (1997). The centrality of financial support from business leaders such as Coors to the modern conservative movement is documented in NicOlE HOPLIN \& RON RoBINSON, Funding FAthers: The Unsung Heroes of the Conservative Movement (2008).

116. See Patrick Allitt, The Conservatives: Ideas and Personalities Throughout American HistORY 2 (2009) (discussing how "before the 1950s there was no such thing as a conservative movement in the United States [emphasis included]").

117. Id. at $225,228-34$.

118. See Phillips-Fein, supra note 106, at xii.

119. See Thomas W. Evans, The Education of Ronald Reagan: The General Electric Years (2006).

120. Id. at 24 .

121. See Phillips-FeIn, supra note 106, at 162, 165.

122. See John Micklethwait \& Adrian Wooldridge, The Right Nation: Conservative Power in America 77-78 (2004); John Judis, The Paradox of American Democracy: Elites, Special Interests, AND the Betrayal of the Public Trust 9 (2000).

123. See PHILlips-FeIn, supra note 106, at 161.

124. See R.C. Gerstenberg, To Tell the Truth, N.Y. TIMEs, Dec. 29, 1972, at A23.

125. See Oliver A. Houck, With Charity for All, 93 YALE L. J. 1415, 1458-60 (1984).

126. See Timothy L. Foden, The Battle for Public Interest Law: Exploring the Orwellian Nature of the Freedom Based Public Interest Movement, 4 CONN. PUB. INT. L. J. 210, 212-14 (2005). See also Ann Southworth, Conservative Lawyers and the Contest Over the Meaning of "Public Interest Law"," 52 UCLA L. REV. 1223, 1241-1245 (2005) (discussing the great numbers of similar litigation centers launched in the seventies and eighties and calling the Powell memorandum an "important moment in the mobilization of business constituencies behind new public interest law organizations”).

127. See Carl T. Bogus, Genuine Tort Reform, 13 Roger WiLliams U. L. Rev. 1, 1-5 (2008).

128. See Zygmunt J.B. Plater, Environmental Law in the Political Ecosystem - Coping With The Reality of Politic, 19 PACE ENVTL. L. REV. 423, 483-486 (2002). See also Zygmunt J.B. Plater, Dealing With Dumb and Dumber: The Continuing Mission of Citizen Environmentalism, 20 
J. ENVTL. L. \& Litig. 9 (2005), and Zygmunt J. B. Plater, Theories of the Corporation, 44 TENN. B. J. 14 (2008).

129. See David L. Franklin, What Kind of Business-Friendly Court? Explaining the Chamber of Commerce's Success at the Roberts Court, 49 SANTA CLARA L. REV. 1019, 1019-25 (2009).

130. See John Micklethwait \& Adrian Wooldridge, The Right Nation: Conservative Power in America 77-79 (2004); John Judis, The Paradox of American Democracy: Elites, Special Interests, AND the Betrayal of the Public Trust 9 (2000).

131. See Business' Most Powerful Lobby in Washington, Bus. WeEK, December 20, 1976, at 60.

132. See Robert L. Kerr, Creating the Corporate Citizen: Mobil Oil's Editorial-Advocacy Campaign in The New York Times to Advance the Right and Practice of Corporate Political Speech, 1970-80, 21 AM. JOURNALISM 39-62 (Fall 2004).

133. See Walter Berns, The Corporation's Song: Book and Lyrics by Hobbes, Locke, and Madison. Music by Mobil Oil? in Prosperity and Freedom: The Founding Fathers, Commerce, AND THE CORPORATION 1-10 (1981).

134. See, e.g., KIM McQuaId, Big Business and Public Policy in Contemporary United States, in 11 Business AND GOvERNMENT IN AMERICA Since 1870 177-79 (Robert F. Himmelberg, ed., 1994); James Q. Wilson, The Corporation as a Political Actor, in Carl Kaysen, ed., The American Corporation Today 413-22 (1996); David Vogel, Fluctuating Fortunes: The Political Power of Business in AMERICA 195-97 (1989).

135. See Thomas Byrne Edsall, The New Politics of Inequality 107-108 (1984).

136. 447 U.S. 557 (1980).

137. 447 U.S. 557 (1980).

138. 316 U.S. 52, 54 (1942).

139. 376 U.S. 254 (1964).

140. 376 U.S. 254, 266 (1964).

141. Id.

142. Personal notes by Justice Powell (20 March 1973) at 1, Pittsburgh Press Co. v. Pittsburgh Commission. on Human Relations, 413 U.S. 376 (1973) in LFP Papers.

143. Pittsburgh Press, 413 U.S. at 388 (1973).

144. Conference Notes of Justice Powell (23 March 1973) at 1, 413 U.S. in LFP Papers. After oral arguments were heard in a case, the justices would meet together privately in conference to discuss where each stood on the case at that point. Powell's files include notes that he made for his own reference at such conferences during his tenure on the Court.

145. Id.

146. Id.

147. Id.

148. Id.

149. Personal notes by Justice Powell (22 March 1973) at 1-2, 413 U.S. in LFP Papers.

150. 413 U.S. at 385 .

151. Id. at 385 . 
152. Id. at 387.

153. Id. at 388 .

154. Id.

155. Id. at 389 .

156. 418 U.S. 298 (1974).

157. 418 U.S. 298 (1974). Justice Douglas declined to join either opinion, but did support the judgment announced in Justice Blackmun's opinion.

158. Id. at 303.

159. Id.

160. Id. at 303-304.

161. Id. at 304.

162. Id. at 314 (Brennan, J., dissenting).

163. Id. at 314-15.

164. Conference Notes of Justice Powell (1 March 1974) at 1, 418 U.S. in LFP Papers.

165. Personal notes by Justice Powell (31 May 1974) at 6, 418 U.S. in LFP Papers.

166. 421 U.S. 809 (1975).

167. Conference Notes of Justice Powell (20 December 1974) at 1, 421 U.S. in LFP Papers.

168. Personal notes by Justice Powell (6 February 1974) at 1, 421 U.S. in LFP Papers.

169. Id. at 811-14.

170. 421 U.S. at 819-20.

171. Id. at 823,825 .

172. 425 U.S. 748 (1976).

173. Id. at 762 (quoting 413 U.S. at 385).

174. Id. at 773 .

175. Id. at 770 .

176. Id. at 765 .

177. Id. at 771-72.

178. Id. at 771, n. 24.

179. Id. at 776-77 (Stewart, J., concurring).

180. Id. at 777 .

181. Id.

182. Id. at 777-78.

183. Id. at 780 .

184. Id. (quoting 421 U.S. 809, 822 (1975)) (citing 425 U.S. at 762-65, 770, n. 8). 
185. Id. at 780-81.

186. Personal notes by Justice Powell (19 August 1975) at 2-3, 425 U.S. in LFP Papers.

187. Conference Notes of Justice Powell (14 November 1975) at 1, 425 U.S. in LFP Papers.

188. Personal notes by Justice Powell (19 August 1975) at 2, 425 U.S. in LFP Papers.

189. Letter from Justice Powell to Justice Blackmun (29 March 1976) at 1-2, 425 U.S. in LFP Papers (emphasis included).

190. Letter from Justice Brennan to Justice Blackmun (31 March 1976) at 1, 425 U.S. in LFP Papers.

191. 425 U.S. at 773, n. 25.

192. Id. at 774, (Burger, C.J., concurring).

193. 431 U.S. 86 (1977).

194. Id. at 97.

195. Id. at 88 .

196. Personal notes by Justice Powell (4 March 1977) at 2, 431 U.S. in LFP Papers.

197. 431 U.S. at 96.

198. Id.

199. Id.

200. Id. at $96-97$.

201. 433 U.S. 350 (1977).

202. Id. at 379.

203. Id. at 365 (quoting 425 U.S. at 770).

204. Id. at 384 .

205. Id. at 383 .

206. Conference Notes of Justice Powell (21 January 1977) at 1, 433 U.S. in LFP Papers.

207. Memorandum from Gene Comey to Justice Powell (10 June 1977) at 1, 433 U.S. in LFP Papers.

208. Personal notes by Justice Powell (9 May 1977) at 1-34, 433 U.S. in LFP Papers.

209. 433 U.S. at 389-404 (Powell, J., dissenting).

210. Id. at 389 (citing 433 U.S. at 384).

211. Id. at 389 .

212. Id. at 397.

213. Id.

214. Personal notes by Justice Powell (7 September 1977) at 1, 436 U.S. 447 (1978) in LFP Papers.

215. 436 U.S. 447 (1978).

216. 436 U.S. at 449-54. 
217. Id. at 469 (Marshall, J., concurring).

218. Id. at 449 .

219. Letter from Justice Blackmun to Justice Powell (12 May 1978) at 1, 436 U.S. in LFP Papers.

220. Id. at 454-55.

221. Id. at 456 .

222. Id. at 455 .

223. 440 U.S. 1 (1979).

224. Rogers v. Friedman, 438 F.Supp. 428, 431 (E.D. Tex. 1977).

225. Personal notes by Justice Powell (24 October 1978) at 1, 440 U.S. in LFP Papers (emphasis included).

226. Conference Notes of Justice Powell (11 October 1978) at 1, 440 U.S. in LFP Papers.

227. Id. at 1 .

228. 440 U.S. at 13-16.

229. Id. at 13 .

230. 447 U.S. 557 (1980).

231. 447 U.S. at 566: "At the outset, we must determine whether the expression is protected by the First Amendment. For commercial speech to come within that provision, it at least must concern lawful activity and not be misleading. Next, we ask whether the asserted governmental interest is substantial. If both inquiries yield positive answers, we must determine whether the regulation directly advances the governmental interest asserted, and whether it is not more extensive than is necessary to serve that interest."

232. Justice Powell thus established the test for considering regulation of commercial speech beneath the higher level of strict scrutiny applied to regulation of political expression but above the lower level of rational-basis scrutiny applied to regulations that do not infringe upon fundamental rights.

233. Memorandum from David O. Stewart to Justice Powell (25 April 1980) at 1, 447 U.S. in LFP Papers.

234. Conference Notes of Justice Powell (19 March 1980) at 1, 447 U.S. in LFP Papers.

235. Chief Justice Burger, and Justices Stewart, White and Marshall joined Justice Powell's majority opinion in full. Justices Brennan, Blackmun, and Stevens each joined the judgment and authored a separate concurrence.

236. David O. Stewart, e-mail message to author, 10 December 2009. Stewart is now a veteran trial lawyer with the Ropes \& Gray firm in Washington.

237. Memorandum from Justice Powell to Stewart (28 April 1980) at 1-2, 447 U.S. in LFP Papers.

238. Id. at 1.

239. Central Hudson, 447 U.S. at 566.

240. Memorandum from Justice Powell to Stewart (28 April 1980) at 4, 447 U.S. in LFP Papers.

241. Id. at 2 .

242. Memorandum from Justice Powell to Stewart (28 April 1980) at 2-3, Central Hudson, 447 U.S. in LFP Papers. 
243. 447 U.S. at 566-69.

244. 447 U.S. at 570.

245. 447 U.S. at 570-71.

246. 453 U.S. 490 (1981).

247. Id. at 503-17.

248. Id. at 513 .

249. Id.

250. 463 U.S. 60, 66-67 (1983).

251. Id. at 67-68.

252. Id. at 68. (quoting 447 U.S. at 563).

253. Id. at 69-75.

254. 478 U.S. 328 (1986).

255. Id. at 340-44.

256. Id. at 350 (Brennan, J., dissenting).

257. Id. at 345-46.

258. See Personal notes by Justice Powell (24 May 1986) at 1, 478 U.S. in LFP Papers.

259. See supra notes 58-71 and 217-222 and accompanying text for fuller discussion of the cases involved in that evolution of the Court's commercial-speech doctrine.

260. 507 U.S. 410 (1993).

261. Id. at 509. Justice Stevens was joined in that part of his opinion by Justices Anthony M. Kennedy, Clarence Thomas, and Ruth Bader Ginsburg.

262. Id.

263. Id. at 514.

264. Id.

265. Id. at 531 (O’Connor, J., concurring). Justice O'Connor was joined in that concurrence by Chief Justice Rehnquist and Justices Stephen G. Breyer and David H. Souter.

266. Id. at 531-32.

267. See 425 U.S. $748,770,771$, n. 24. (1976).

268. See 431 U.S. 86, 96-97 (1977).

269. See 433 U.S. 350, 384 (1977).

270. See 436 U.S. 447, 455 (1978).

271. See 447 U.S. 557, 563 (1980).

272. Personal notes by Justice Powell (19 August 1975) at 2, 425 U.S. in LFP Papers.

273. Jeffries, Justice Lewis F. Powell, Jr., 195.

274. Id. at 195 
275. LAWyer Advertising at the Crossroads 35 (1995).

276. Id. at 15-17.

277. Lori B. Andrews, Birth of a Salesman: Lawyer Advertising and Solicitation 2-9 (1980).

278. 416 U.S. 600 (1974).

279. Id. at 624 (Powell, J., concurring).

280. Id. at $624-25$.

281. Id. at 627 (asserting that the Mitchell ruling correctly addressed the undesirable potential for imbalance that Justice Powell contended had been created in the Court's ruling in Fuentes v. Shevin, 407 U.S. 67 (1972), a case involving similar questions).

282. David O. Stewart, e-mail message to author, 16 February 2011.

283. See FRED H. MILLER, THE ABCS OF THE UCC viii (2002). The U.C.C., developed by the National Conferences of Commissioners on Uniform State Laws and the American Law Institute, has been enacted by the legislatures of the fifty states, the District of Columbia, Puerto Rico, and the U.S. Virgin Islands, all of which represent jurisdictions that are members of the N.C.C.U.S.L. Id. at 1.

284. Id. at 25 .

285. Id. at 29.

286. See Farber, supra note 7, at 389.

287. Reza R. Dibadj, The Political Economy of Commercial Speech, 58 S.C. L. Rev. 913, 930 (2007).

288. See MILLER, supra note 82, at 2.

289. U.C.C. § 1-302(b) (2007).

290. JAMES J. White \& ROBERT S. SuMmers, UNIFORM COMMERCIAL CODE 137 (6 th $^{\text {ed. }}$ 2010).

291. U.C.C. § 1-304 (2007).

292. Carol L. Chomsky, Christina L. KunZ, Linda J. Rusch, ELIZABEth R. SCHILTZ, Selected COMMERCIAL STATUTES 47 (2007).

293. William A. Hancock, ED., Corporate Counsel's Guide to The UNIFORM Commercial Code 1.002 (2002).

294. Id.

295. See WHITE, supra note 290, at 517.

296. Id. at 518.

297. See Vladeck, supra note 78 , at 1086.

298. See Farber, supra note 7, at 407-408.

299. Id. at 386 .

300. Richard A. Posner, Free Speech in an Economic Perspective, 10 SUFFOLK L. REV. 1, 22-23 (1986).

301. Id. at 26 .

302. Id. at 22 . 
303. Id. at 26.

304. Id. at 39-40.

305. Id. at 23.

306. See Richard A. Posner, A FaIlure of Capitalism: The Crisis of 'O8 and the Descent into DEPRESSION 274 (2009).

307. See Ronald Reagan, First Inaugural Address, Jan. 20, 1981, in KURT RITTER \& DAVID HENRY, RoNALD REAGAN: THE GREAT COMMUNICATOR 156 (1992).

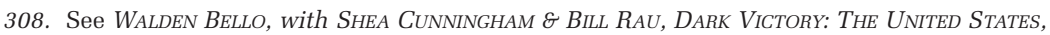
Structural adjustment, and Global Poverty 3 (1994).

309. Id.

310. See Thomas Frank, ONE MARKET UNDER GoD: EXTREME CAPITALISM, MARKET Populism, and the END OF ECONOMIC DEMOCRACY XV (2000).

311. See William Jefferson Clinton, State of the Union Address, Jan. 23 1996, White House, accessed March 12, 2011 at: http://clinton4.nara.gov/WH/New/other/sotu.html.

312. See POSNER, supra note 306, at 135.

313. See Marina V.N. Whitman, The Corporation in Society, in Jack BEATTY, ED., Colossus: How THE CORPORATION CHANGED AMERICA 477-79, 489 (2001).

314. See Isadore Barmash, That Angry Voice? It's a Consumer's, N.Y. Times, Jan. 11 1970, at 12:29.

315. See Business Lobbying: Threat to the Consumer Interest, CONSUMER REPORTs, Sept. 1978, at 527.

316. See David Vogel, Fluctuating Fortunes: The Political Power of Business in America 195-98 (1989).

317. See Business Lobbying, supra note 315, at 527.

318. See Thomas Byrne Edsall, The New Politics of Inequality 107-108, 131 (1984).

319. See FRANK, supra note 310, at 173, 179, 220.

320. See Business' Most Powerful Lobby in Washington, supra note 131, at 60.

321. See The Embattled Businessman, NEWswEEK, Feb. 16, 1976, at 58.

322. See Scott R. Bowman, The Modern Corporation and American Political Thought 145 (1996).

323. See Victor Godinez, Change in Store for Pizza Hut, DALLAS MORNING NEWS, Dec. 24 2003, at D1.

324. See, e.g., Torches of Freedom, Museum of Public Relations, accessed March 122011 at: http://www.prmuseum.com/bernays/bernays_1929.html.

325. See, Wendy L. WALL, INVENTING tHE AmERICAN WAY 54-60 (2008).

326. The New York Times was the media venue that Mobil chose as the centerpiece of its effort to disseminate messages aimed at influencing the broader marketplace of the ideas. Mobil did publish some of the messages that appeared in the Times (as well as additional messages that were similarly themed) in other newspapers and magazines, but it was in the Times that Mobil most extensively and prominently disseminated its editorial-advocacy campaign of the 1970 s.

327. See How Good Are Advocacy Ads? Dun’s Review, June 1978, at 76. 
328. See Robert L. Heath, Strategic Issues Management: Organizations and Public Policy CHALLENGES 208 (1997).

329. See Oil is Not a Cottage Industry, Advertisement, N.Y. TIMES, July 1, 1976, at 1:29.

330. See Peter Ellis Jones, OIL: A Practical Guide to the ECONOMics of World Petroleum 8 (1988).

331. See, e.g., Os Guinness, The American Hour: A Time of ReCKOning and the OnCE AND Future Role of FAITH (1993); and PHILIP JENKINS, DECADE OF NightMares: THE END OF THE SIXTIES AND THE MAKING OF EIGHTIES AMERICA (2006).

332. See Dear Mr. Sulzberger, Advertisement, N.Y. TIMES, Sept. 25 1980, at 1:27.

333. See Herbert Schmertz with William Novak, Goodbye to the LoW Profile: The Art of Creative CONFRONTATION 23 (1986).

334. See Some Energy Options That Haven’t Even Been Discussed, Advertisement, N.Y. TIMES, August 2, 1979, at 1:17.

335. See Imagine Tomorrow Without Argument, Advertisement, N.Y. TIMES, August 16, 1979, at $1: 23$.

336. See Embarrassment of Riches, Advertisement, N.Y. TIMES, Oct. 9, 1980, at 1:35.

337. See To Have or Have Not? Advertisement, N.Y. TIMES, Oct. 16, 1980, at 1:31.

338. See The Fork in the Road, Advertisement, N.Y. TIMES, Oct. 30, 1980, at 1:27.

339. See First Inaugural Address, supra note 304, at 156.

340. Id., at 157 .

341. See Free Enterprise, radio address, April 16, 1979, in KIRON K. SKINNER, ANNELISE ANDERSON,

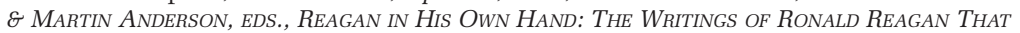
REVEAL His REVOLUTIONARY VISION FOR AMERICA 228 (2001).

342. See Economics I, radio address, April 31, 1978, id. at 258-59.

343. See Paperwork and Bureaucrats, radio address, September 21, 1976, id. at 297.

344. See Regulations, radio address, March 12, 1975, id. at 294.

345. Id., at 295. For a fuller study of the development of Reagan's pro-business and anti-government rhetoric, see EVANS, supra note 119, at 3-30.

346. See Liberals, Logical Allies of Business, Advertisement, N.Y. TIMES, June 22, 1978, at 1:23.

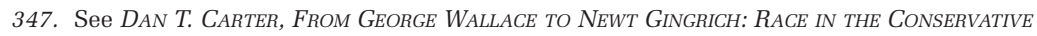
COUNTERREVOLUTION, 1963-1994 14 (1996).

348. Id., at 23.

349. See NAOMI KLEIN, NO LOGO 3-30 (1999).

350. See Robert Kuttner, EVERything For SALE: The Virtues and Limits of MARKetS 3-10 (1997).

351. See James Arnt Aune, Selling the Free Market: The Rhetoric of EConomic Correctness 4 (2001).

352. See KENNETH S. FRIEDMAN, MYtHS OF THE FREE MARKET 1-7 (2003).

353. See Justin Lahart, Corporate Tax Burden Shows Sharp Decline,” WALL ST. J., 13 April 2004, at C3.

354. See Lynnley Browning, Study Finds Accelerating Decline in Corporate Taxes,” N.Y. TIMES, 
Sept. 23, 2004, at C3.

355. See Joe Bel Bruno, Associated Press, Corporate America Has Record Cash Stockpiles on Hand," OKLAHOMAn, May 28, 2006, at C8.

356. See Felicity Barringer, New Priorities in Environment,” N.Y. TIMES, Sept. 14, 2004, at A1.

357. See Christopher Drew and Richard A. Oppel, Jr., How Power Lobby Won the Battle of Pollution Control at E.P.A.," N.Y. TIMES, March 6, 2004, at A1.

358. For examples of this phenomenon at work, see, e.g., FRANK LUNTZ, WORDS THAT WORK: IT'S Not What You SaY, IT'S What PEOPLE HeAR (2007); and George Lakoff, Framing the Dems, AMERICAN Prospect, Sept. 1, 2003, at 32.

359. See James Glanz, Scientists Say Administration Distorts Facts, N.Y. TIMES, Feb. 19, 2004, at A18.

360. See, e.g., Ross Gelbspan, Boiling Point: How Politicians, Big OIl and Coal, Journalists, and ACtivists aRe FueLING the Climate CRISIS (2004).

361. See, e.g., Robert W. MCChesney \& John Nichols, Our Media, Not Theirs: The Democratic StrugGle AgAinst Corporate MEDIA 31-45 (2002).

362. See Editorial, Don’t Blame the New Deal, N.Y. TIMES, Sept. 28, 2008, at WK9.

363. See Andrew Ross Sorkin, Too Big to Fail: The Inside Story of How Wall Street and Washington Fought to SAVE the Financial System From CRISIS - and THEMSELVES 3 (2009).

364. See Stephen Labaton and Edmund L. Andrews, A Costly Bailout: Federal Intervention is Bid for Stability - C.E.O.'s Ousted, N.Y. TIMES, Sept. 8, 2008, at A1.

365. See Andrew Ross Sorkin, Edmund L. Andrews, Eric Dash, Michael J. de la Merced, Louise Story, and Ben White, Merrill is Sold: Failing to Find Buyer, Lehman Bros. is Set to Wind Down, N.Y. TIMES, Sept. 15, 2008, at A1.

366. Id.

367. See Matthew Karnitschnig and Liam Pleven, AIG Seeks Huge Loan as Stock Dives 61\%, WALL ST. J., Sept. 16, 2008, at A1.

368. See Mary Williams Walsh and Michael J. de la Merced, A Lifeline for A.I.G. from State, N.Y. TIMES, Sept. 16, 2008, at C1.

369. See Eric Dash and Andrew Ross Sorkin, Fed's Bailout of A.I.G. Came After Frantic Search for Rescuer, N.Y. TIMES, Sept. 18, 2008, at C1.

370. See Louise Story and Edmund L. Andrews, Change Arrives, with a Sense that Wall Street's Boom Times Are Over, N.Y. TIMES, Sept. 16, 2008, at C1.

371. See Alex Berenson, Fearing Worse to Come, Investors Drive Dow to Biggest Loss Since '01, N.Y. TIMES, Sept. 16, 2008, at C7.

372. See John Hilsenrath, Serena Ng, and Damian Paletta, Worst Crisis Since '30s, With No End Yet in Sight, WALL ST. J., Sept. 18, 2008, at A1.

373. See David M. Herszenhorn, Federal Aid to Detroit Seems Likely, N.Y. TIMES, Sept. 18, 2008, at C1.

374. See Vikas Bajaj, Governments Strive to Provide Credit and Assurance, N.Y. TIMES, Sept. 18, 2008, at A1.

375. See Edmund L. Andrews, Vast Bailout is Proposed in Bid to Stem Economic Crisis, N.Y. TIMES, Sept. 19, 2008, at A1. 
376. See Deborah Solomon, Liz Rappaport, Damian Paletta, and Jon Hilsenrath, Shock Forced Paulson's Hand, WALL ST. J., Sept. 20-21, 2008, at A1.

377. Id.

378. See transcript, Bill Moyers Journal, Oct. 10, 2008, accessed March 12, 2011 at: http://www.pbs.org/moyers/journal/10102008/transcript4.html.

379. See The Week That Changed American Capitalism, WALL ST. J., Sept. 20-21, 2008, at A5.

380. See Deborah Solomon and Damian Paletta, U.S. Bailout Plan Calms Markets, But Struggle Looms Over Details, WALL ST. J., Sept. 20-21, 2008, at A1.

381. See Sheryl Gay Stolberg and David Herszenhorn, President Tells Nation Inaction May Bring a Long Recession, N.Y. TIMES, Sept. 25, 2008, at A1.

382. See Andrew Ross Sorkin, A Bailout Above the Law, N.Y. TIMES, Sept. 23, 2008, at C1.

383. See Carl Hulse and David Herszenhorn, House Rejects Bailout Package, 228-205; Stocks Plunge, N.Y. TIMES, Sept. 30, 2008, at A1.

384. See Greg Hitt and Deborah Solomon, Bush Signs Bailout Bill As Economy Slips Further, WALL ST. J., Oct. 4-5, 2008, at A1.

385. See David Wessel, In Turmoil, Capitalism Sets New Course, WALL ST. J., Sept. 20-21, 2008, at A1.

386. See Edmund L. Andrews, Greenspan Concedes Flaws in Deregulatory Approach, WALL ST. J., Oct. 24, 2008, at B1.

387. See SORKIN, supra note 363, at 529.

388. See POSNER, supra note 306, at xii.

389. Id. at 315-16.

390. Id. at 319,328 .

391. See Charles Gasparino, The Sellout: How Three Decades of Wall Street Greed and Government Mismanagement Destroyed the Global FinanCial System 15-16 (2009).

392. See Scott Patterson, The Quants: How a New Breed of Math Whizzes Conquered WaLL STREET AND NEARLY DESTROYED IT 3 (2010).

393. Id. at 7-12.

394. Id. at 12 .

395. See Michael W. Hudson, How a Gang of Predatory Lenders and Wall Street Bankers FLEECED AMERICA — AND SPAWNED a GLOBAL CRISIS 6 (2010).

396. Id. at 9-10.

397. See Bethany McLean \& Joseph Nocera, All the Devils Are Here: The Hidden History of the FINANCIAL CRISIS 268 (2010).

398. See Vicky Ward, The DeVIL'S CAsino: Friendship, Betrayal, and the High-StaKes Games Played INSIDE LEHMAN BROTHERS 164 (2010).

399. See transcript, Bill Moyers Journal, April 23, 2010, accessed March 12, 2011 at: http://www.pbs.org/moyers/journal/04232010/transcript4.html.

400. Id. at 164-72.

401. See Greg Farreld, Crash of the Titans: Greed, Hubris, The Fall of Merrill Lynch and the 
NEAR-COLLAPSE OF BANK OF AMERICA 4 (2010).

402. Id. at 2-4.

403. Id. at 417 .

404. See Suzanne McGee, Chasing Goldman Sachs: How the Masters of the Universe Melted

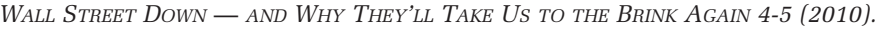

405. Id. at 12 .

406. Id. at 228, 232.

407. Id. at 238.

408. See Michael Lewis, The Big Short: Inside the Doomsday Machine 23 (2010).

409. Id. at 23-24.

410. Id. at 24 .

411. See Larry ELLIOtT and Dan AtKinson, The Gods that FaILED: How BLIND Faith in Markets Has COST US OUR FUTURE 210-11 (2009).

412. See William D. Cohan, House of CARDS: A TALE of Hubris and Wretched Excess on WaLL STREET 318 (2009).

413. See SORKIN, supra note 359, at 6.

414. See Mark T. WiLlams, UNCONTROLLED Risk: THE LESSONS OF LEHMAN BRothers and HoW Systemic Risk Can Still Bring Down the World Financial System 45 (2010).

415. Id. at 105, 118.

416. Id. at 209.

417. See Charles P. Kindleberger, Manias, Panics, and Crashes: A History of Financial Crashes 2 (200).

418. See Peter L. Bernstein, Against the Gods: The Remarkable Story of RisK 330 (1998).

419. See Charles P. Kindleberger, Manias, PANics, and Crashes: A History of Financial Crashes 4 (200).

420. See Memorandum from Lewis F. Powell, Jr., to Eugene B. Sydnor, Jr., supra note 101.

421. See supra notes 26, 61-74, and 259-71 and accompanying text for fuller discussion of the cases involved in that recent phase of the Court's commercial-speech doctrine.

422. Mainstream Marketing Services v. Federal Trade Commission, 358 F.3d 1228, 1236 (10th Cir. 2004), cert. denied, 543 U.S. 812 (2004).

423. United States v. Edge Broadcasting, 509 U.S. 418, 435 (1993).

424. Rubin v. Coors, 514 U.S. 476, 491 (1995).

425. 44 Liquormart v. Rhode Island, 507 U.S. 410, 516 (1993).

426. Lorillard Tobacco v. Reilly, 533 U.S. 525, 567 (2001).

427. Id. at 554

428. Id. at 554-55 (quoting Greater New Orleans Broadcasting v. United States, 527 U.S. 173, 184 (1999)). 